\title{
Assessment of Battery Storage Technologies for a Turkish Power Network
}

\author{
Mustafa Cagatay Kocer ${ }^{1, *}$, Ceyhun Cengiz ${ }^{2}$, Mehmet Gezer ${ }^{3}$, Doruk Gunes ${ }^{3}$, \\ Mehmet Aytac Cinar ${ }^{4}$, Bora Alboyaci ${ }^{5}$ and Ahmet Onen ${ }^{1}$ D \\ 1 Department of Electrical and Electronics Engineering, Abdullah Gul University, Kayseri 38080, Turkey \\ 2 TEIAS, Ankara 06520, Turkey \\ 3 GENETEK, Kocaeli 41275, Turkey \\ 4 Izmit Vocational School, Kocaeli University, Kocaeli 41285, Turkey \\ 5 Department of Electrical Engineering, Kocaeli University, Kocaeli 41040, Turkey \\ * Correspondence: mustafa.kocer@agu.edu.tr; Tel.: +90-352-224-8800
}

Received: 8 May 2019; Accepted: 2 July 2019; Published: 4 July 2019

check for updates

\begin{abstract}
Population growth has brought an increase in energy demand and cost that has a meaningful impact on personal and government expenses. In this respect, governments attach importance to investments in renewable energy resources (RER), which are a sustainable and clean energy source. However, the unpredictable characteristics of RER are a major problem for these clean sources and RER need auxiliary assets. Battery energy storage systems (BESS) are one of the promising solutions for these issues. Due to the high investment cost of BESS, governments act cautiously about accepting and implementing BESS in their power network. Recently, with the improvement of technology, the cost of BESS has been reduced, and therefore battery technologies have begun to be applied to conventional systems. In this study, first, we will review and discuss the current globally state-of-the-art BESS and their applications. Later, attention will be turned to a country-specific study for Turkey.
\end{abstract}

Keywords: battery energy storage systems; energy storage; hybrid energy storage systems; renewable energy resources; frequency regulation; congestion management; energy arbitrage

\section{Introduction}

The process of evolution has continued since the beginning of the universe and positions energy among the top essential components for all creatures. Undoubtedly, electric energy is one of the essential requirements for civilization that is founded and raised by humans which is the most advanced species in the universe. However, humans have realized that our way of generating electricity has become one of the leading environmental problems that endanger the future of rising civilizations. According to [1], nearly $30 \%$ of the greenhouse gas emissions in the atmosphere are due to the fossil fuels used in the generation of electrical energy. Fortunately, as a result of social responsibility movements that have been carried out on a global scale intended to reduce the impact of this problem that threatens our future, the share of fossil fuels used in electricity generation decreases day-by-day. Especially in the last decade, the share of renewable energy resources in power networks has been increasing rapidly under the leadership of wind and photovoltaic (PV) power [2]. However, the problems arising from the chaotic behaviors of renewable energy resources are still a major obstacle to their large scale integration into the power grid [3,4]. Although methods such as forecast studies have made serious progress minimizing the uncertainties of the renewable energy resources (RER), the accuracy and practical applications of these methods have not yet reached the desired point. Therefore, such problems have made it necessary for traditional energy systems to enter into an important evolutionary process. As a 
result of this evolutionary process, energy storage systems (ESS) have a potentially significant role in the modern power grid as a solution, especially to the problems arising from RER.

The concept of energy storage systems includes many different storage technologies. Battery technologies are not the cheapest ESS. However, when the basic features such as energy density, fast response time, round trip efficiency, cycles, lifetime and current technological maturity, and potential future progress are evaluated together, battery technologies have emerged as the most logical ESS choice for grid applications in the last decade. The most popular battery types used in the network at present are lead-acid, nickel-cadmium, sodium-sulfur, lithium-ion, vanadium redox, zinc-bromine, and metal-air [5-7].

Although only $1 \%$ of the globally installed energy storage capacity belongs to BESS, it is a storage technology that has received the most investment among these systems in the last decade [5-7]. The BESS contribute by stabilizing the grid when load levels are high, as well as support the grid when RER deliver insufficient power output. In addition, these systems serve in a wide range of application areas such as primary/secondary frequency control, congestion management, loss reduction, demand response, etc. [8]. Thus, operational features such as the use and control of the BESS differs according to the purpose needed. However, the planning of BESS investments to serve the desired purpose depends directly on the location and size features of these systems.

One aim of this study is to identify the potential contribution of BESS in the Turkish power network (TPN). The TPN does not yet have any storage system. Therefore, economic and technological feasibility studies are being conducted to determine storage investments. Within the scope of these studies, interest in the transmission and distribution system operators has focused on batteries as a promising technology. Primarily, the battery systems are expected to contribute to the TPN in the fields of ancillary services, congestion management, and energy arbitrage. This article presents a broad review of the literature on the approaches used in BESS technologies in terms of size and selection of a location according to their responsibilities in the power grid. Additionally, as a real-world application of BESS, three different case studies from the Turkish Power Network are presented. This paper is organized as follows: Section 2 gives brief information about battery technologies; Section 3 describes the solutions presented by the BESS in a power network; Section 4 is reserved for challenges and opportunities in this area; real-world cases from TPN are given in Section 5; and finally, the conclusion is drawn in Section 6.

\section{Battery Energy Storage Technologies}

A battery energy storage system is a storage unit that act as a source in the power network by converting the energy they store into electrical energy for use in case of a need. Since BESS are relatively small and portable, they often do not encounter location problems in the grid.

\subsection{Lithium-Ion Batteries}

The most common form of lithium-ion batteries is comprised of positive electrode (cathode) of lithium oxides, negative electrode (anode) of graphite, electrolytes of lithium salt, and resolvent. The structure of a lithium-ion (Li-ion) battery is shown in Figure 1. 


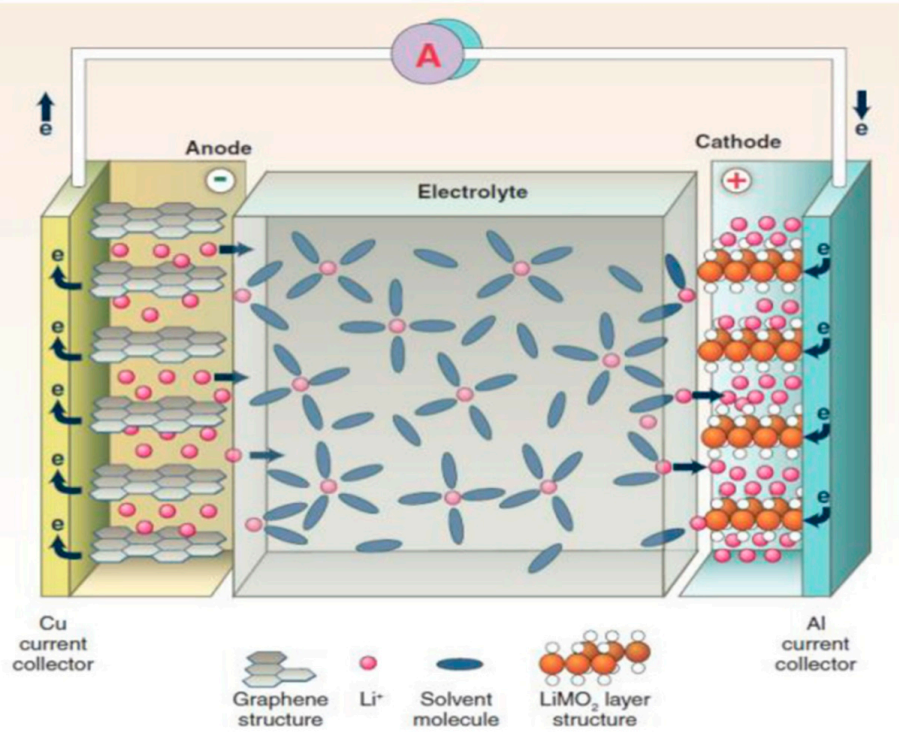

Figure 1. Structure of a lithium-ion (Li-ion) battery [9].

Since they are highly efficient and have no memory effect and high energy density, lithium-ion batteries are frequently used in portable electronic equipment [10]. Charging and discharging management of these batteries is quite flexible, and therefore they do not have to be fully charged or fully discharged. Over the years, with the development of technology, the number of life cycles has also increased. Today, 3000 to 4000 cycles are reached thanks to more durable materials. In fact, with the help of some new Li-ion technologies, values exceeding 15,000 cycles are achieved. The specific energy of the battery cell can reach $200-300 \mathrm{Wh} / \mathrm{kg}$ [11]. When it is examined in terms of security, there are some risks when the Li-ion batteries are overloaded, or the temperature limits are exceeded [12].

The optimum operating temperature of Li-ion batteries is $25^{\circ} \mathrm{C}$ [13]. In addition, in the literature, Li-ion batteries were tested at $-70{ }^{\circ} \mathrm{C}$ and results showed that they continued to work even at these temperatures [14].

\subsection{Redox Flow Batteries}

Redox flow batteries are systems where some or all of the energy is stored together with chemicals in tanks outside the battery. The chemical reaction required for the charging or discharging process is the result of stored chemicals contacting the electrodes. Some examples of redox flow batteries are the zinc-bromide redox flow battery, the vanadium redox flow battery (VRB), and the polysulfide bromide battery. The structure of the redox flow battery is shown in Figure 2.

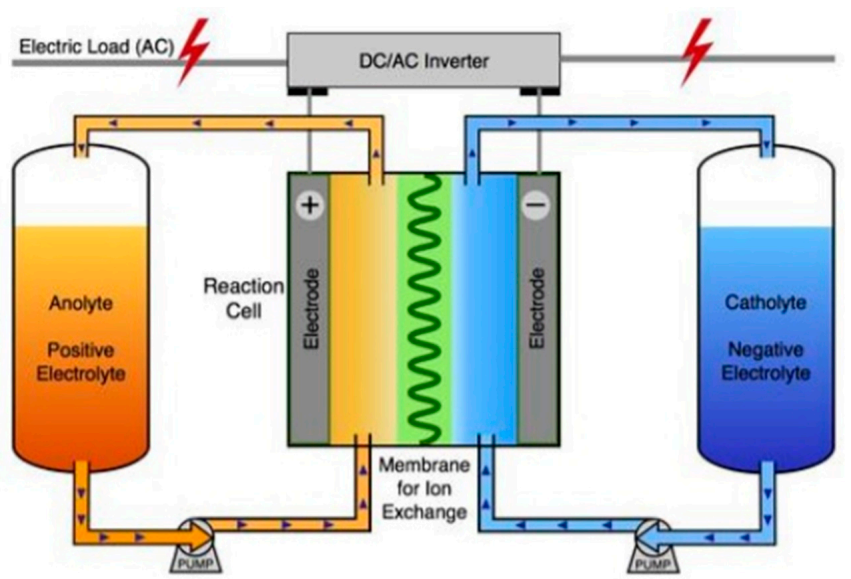

Figure 2. Structure of the redox flow battery [15]. 
One of the most important advantages of this technology over Li-ion batteries is that it is easier to reuse liquid electrolytes. In addition, it has a greater extended life period than that of Li-ion batteries. However, its efficiency is lower [16]. Redox batteries are generally preferred in applications where large areas are available and power needs are lower [17].

Flow batteries store energy in electrolyte solutions as opposed to conventional batteries. The power and energy values of the flow batteries are independent of the storage capacity determined by the amount of electrolyte used and the active area of the cell stack. The stored energy depends on the size of the storage tanks. The power depends on the size of the battery cell. Thus, it is possible to adjust the energy/power ratio.

\subsection{Lead-Acid Batteries}

The oldest and most advanced battery, lead-acid batteries, are rechargeable battery types. Production simplicity and rapid electrochemical reaction are important advantages of this type of battery. The specific energy is approximately $25-40 \mathrm{Wh} / \mathrm{kg}$, and the energy density is between 70 and $100 \mathrm{Wh} / \mathrm{L}$ [18]. These types of batteries are most commonly used as a power source for starting the engine in vehicles. The disadvantage of lead-acid batteries is the damage to the environment due to the heavy metals contained in these batteries [19]. The use of lead-acid batteries in large-scale projects is not suitable due to its battery life and practical difficulties. The efficiency of the lead-acid batteries is around $80 \%$ [20]. The number of life cycles varies between 50 and 1500 depending on usage [21]. Thanks to ongoing studies, technological maturity, and cost-effectiveness, lead-acid batteries are the bestselling battery type in the world, as well, lead-acid batteries have a flexible structure that can be used for different needs. The structure of the lead-acid battery is shown in Figure 3.

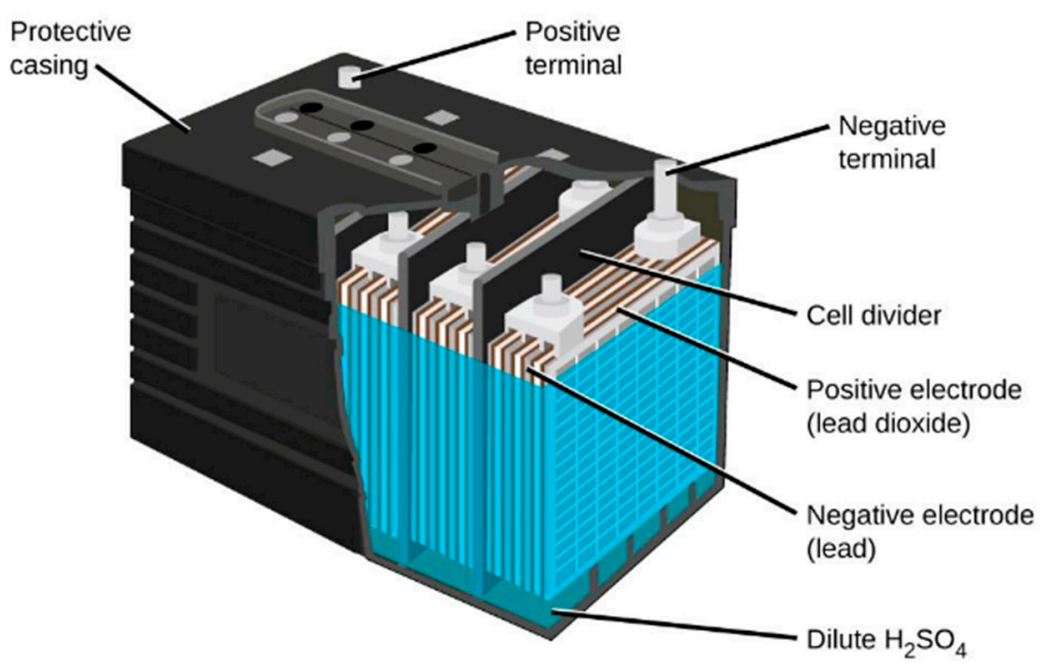

Figure 3. Structure of the lead-acid battery [22].

\subsection{Nickel-Cadmium Batteries}

Nickel-cadmium and nickel metal hydride batteries are the most commonly used types although their efficiency is lower than other nickel-based batteries. Nickel-cadmium (NiCd) batteries have $50 \mathrm{Wh} / \mathrm{kg}$ practical, specific energy density, high reliability, and meager maintenance requirements [23]. They also has a relatively long life [24] and are used in electrical hand tools, portable devices, emergency lighting, UPS, telecommunication, and generator applications [25]. The disadvantages of $\mathrm{NiCd}$ batteries are the relatively high costs due to an expensive manufacturing processes [26] and cadmium is a toxic heavy metal that is produced during the disposal of NiCd batteries that damages the environment $[25,26]$. 


\subsection{Sodium-Sulfur Batteries}

Although relatively new in power system applications, it is the most advanced battery for high temperatures. The life cycle of sodium-sulfur batteries is around 4500 cycles, and their efficiency is around $85 \%$ [27].

Superior energy density, charge/discharge efficiency, service life up to 15 years, and inexpensive materials makes it attractive to use in applications requiring a relatively large-scale BESS [25]. However, it is reported that several conditions limit the use of it in large-scale applications. For example, as sulfur must remain in the molten state to increase efficiency and the high-temperature condition poses a small threat to operators and the environment. The reaction typically requires a temperature of 574-624 K to ensure that the electrodes are in a liquid state, leading to high reactivity. Pure sodium should be protected from the reaction of the system with the atmosphere as there is a risk of explosion when it comes into contact with air [28]. The structure of the sodium-sulfur battery is shown in Figure 4.

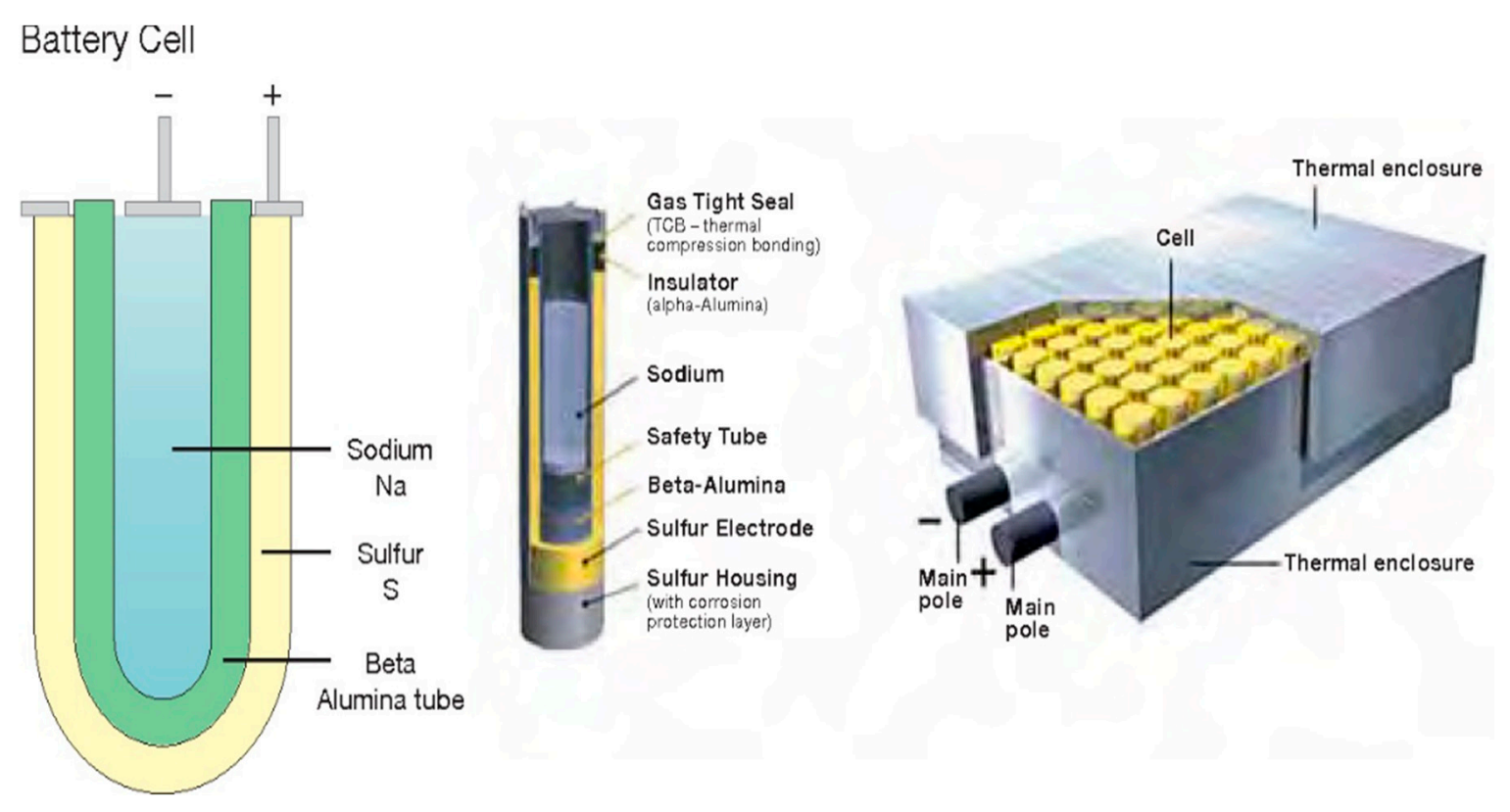

Figure 4. Structure of the sodium-sulfur battery [29].

\subsection{Sodium-Nickel Chloride Batteries}

In comparison to sodium-sulfur batteries, sodium-nickel chloride batteries have a better safety level and higher cell voltage $(2.58 \mathrm{~V})$. Their disadvantages are lower specific energy $(120 \mathrm{Wh} / \mathrm{kg})$ and lower specific power $(150 \mathrm{~W} / \mathrm{kg})$ [23].

\subsection{Metal-Air Batteries}

Metal-air batteries are the most compact and potentially the most expensive batteries, and these batteries have a profound impact on the environment. The most significant disadvantage of such batteries is that they are difficult to charge [30,31]. The structure of the metal-air battery is shown in Figure 5. 


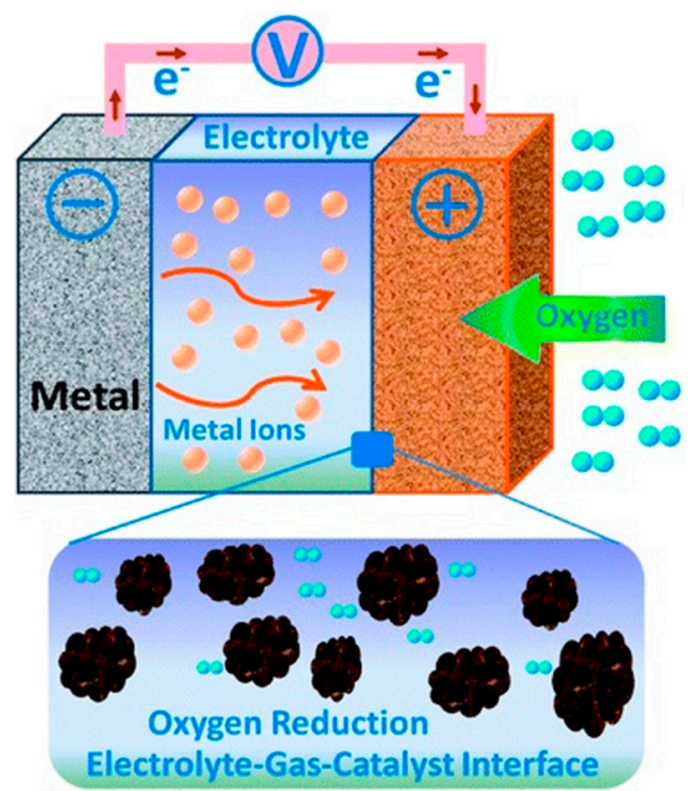

Figure 5. Structure of the metal-air battery [32].

The rechargeable metal-air batteries that are being developed have only a few hundred charges/discharge life cycle, and their efficiency is below 50\%. Large metals that have higher energy density, such as aluminum and zinc, are used in these types of batteries.

\subsection{Comparison of Battery Energy Storage Technologies}

The comparison of battery energy storage technologies for distribution networks is summarized in Tables 1 and 2.

Table 1. Comparison of technical properties of different BESS [5,33-41].

\begin{tabular}{|c|c|c|c|c|c|c|c|}
\hline $\begin{array}{c}\text { Battery } \\
\text { Technologies }\end{array}$ & $\begin{array}{l}\text { Applicable } \\
\text { Capacity } \\
\text { (MW) }\end{array}$ & $\begin{array}{c}\text { Efficiency } \\
(\%)\end{array}$ & $\begin{array}{l}\text { Respond } \\
\text { Time (ms) }\end{array}$ & Life (cycle) & $\begin{array}{l}\text { Investment } \\
\text { Cost }(\$ / k W h)\end{array}$ & $\begin{array}{l}\text { Charge } \\
\text { Discharge } \\
\text { (Time) }\end{array}$ & $\begin{array}{c}\text { Environmental } \\
\text { Impact }\end{array}$ \\
\hline Lead-acid & $0-40$ & $70-90$ & $5-10$ & $3-15(1500)$ & $200-400$ & $\begin{array}{l}\text { min-day } \\
\text { sec-hour }\end{array}$ & medium \\
\hline UltraBattery & $0-36$ & - & 5 & $3-15(3000)$ & 200 & $\begin{array}{l}\text { min-day } \\
\text { sec-hour }\end{array}$ & medium \\
\hline Sodium-sulfur & $0.05-34$ & $80-90$ & 1 & $10-15(2500-4500)$ & $300-500$ & $\begin{array}{l}\text { sec-hour } \\
\text { sec-hour }\end{array}$ & medium \\
\hline Nickel-cadmium & $0-40$ & $60-65$ & $1-1000$ & $10-20(2000-3500)$ & $400-2400$ & $\begin{array}{l}\text { min-day } \\
\text { sec-hour }\end{array}$ & medium \\
\hline Metal-air & $0-0.01$ & 50 & $1-1000$ & $-(100-300)$ & $10-60$ & $\begin{array}{l}\text { hour-month } \\
\text { sec- } 24+\text { hour }\end{array}$ & low \\
\hline
\end{tabular}


Table 2. Advantages, disadvantages, and applications of different BESS [5,34,35,39-41].

\begin{tabular}{|c|c|c|c|c|c|c|c|c|}
\hline & \multirow{2}{*}{ Advantages } & \multirow{2}{*}{ Disadvantages } & \multicolumn{6}{|c|}{ Applications } \\
\hline & & & Power Quality & Demand Management & Load Leveling & Grid Extension & Grid Support & Voltage Regulation \\
\hline Lead-acid & Low investment cost & Low energy density & $\sqrt{ }$ & $\sqrt{ }$ & $\sqrt{ }$ & $\sqrt{ }$ & $\sqrt{ }$ & $\sqrt{ }$ \\
\hline UltraBattery & $\begin{array}{l}\text { Lower investment costs and better } \\
\text { performance than lead-acid batteries }\end{array}$ & Low energy density & $\sqrt{ }$ & $\sqrt{ }$ & $\sqrt{ }$ & & $\sqrt{ }$ & $\sqrt{ }$ \\
\hline $\begin{array}{l}\text { Sodium-sulfur } \\
\quad(\mathrm{NaS})\end{array}$ & High energy density and efficiency & $\begin{array}{l}\text { High production cost, } \\
\text { recycling need } \\
\text { for sodium }\end{array}$ & $\sqrt{ }$ & $\sqrt{ }$ & $\sqrt{ }$ & $\sqrt{ }$ & $\sqrt{ }$ & $\sqrt{ }$ \\
\hline $\begin{array}{l}\text { Lithium-ion } \\
\text { (Li-ion) }\end{array}$ & $\begin{array}{l}\text { High efficiency with high energy and } \\
\text { power density }\end{array}$ & $\begin{array}{l}\text { High cost of lithium and } \\
\text { the need for recycling }\end{array}$ & $\sqrt{ }$ & $\sqrt{ }$ & $\sqrt{ }$ & $\sqrt{ }$ & $\sqrt{ }$ & $\sqrt{ }$ \\
\hline $\begin{array}{l}\text { Nickel-sadmium } \\
\quad(\mathrm{NiCd})\end{array}$ & $\begin{array}{l}\text { High power and energy density } \\
\text { and efficiency }\end{array}$ & Highly toxic components & $\sqrt{ }$ & $\sqrt{ }$ & $\sqrt{ }$ & $\sqrt{ }$ & $\sqrt{ }$ & $\sqrt{ }$ \\
\hline Metal-air & $\begin{array}{l}\text { Low cost, high energy density and } \\
\text { environmentally friendly technology }\end{array}$ & Low recharging ability & $\sqrt{ }$ & $\sqrt{ }$ & $\sqrt{ }$ & $\sqrt{ }$ & $\sqrt{ }$ & $\sqrt{ }$ \\
\hline
\end{tabular}




\section{Objective of BESS}

In this section, the methods used in the planning and control of BESS are reviewed in order to find solutions to some problems that are experienced in power networks.

\subsection{Loss Reduction}

The primary purpose of power systems throughout history has been to meet the power needs of consumers reliably and economically. In this respect, the energy industry and academic studies have made significant progress in order to increase efficiency. Studies to reduce losses in distribution and transmission networks have also resulted because of this goal.

Chad Abbey and Géza Joós [4] determined the battery capacity using the stochastic optimization method by considering wind penetration levels, storage efficiency, and diesel operation strategies. The results showed a significant reduction in losses with optimum storage capacity. In [42], the authors obtained the most suitable location, capacity, and control strategy for the battery system using a mixed-integer linear programming-based analytical method. The researchers in [43] made significant advances in power loss reduction of distribution networks using mixed integer nonlinear programming to determine the role, size, and placement of battery storage systems. A study by [44] discussed how to optimally operate the distributed energy storage devices in a power system with large amounts of wind generation. T. Funabashi et al. [45] used the tabu search-based evolutionary technique for cost and capacity planning of the battery system. Jun Xiao et al. [46] used a two-level optimization method to determine the optimum location and capacity for the battery system and then minimized the losses with the help of the optimal power flow method. In [47], the authors determined battery location and size using the mixed integer second-order cone programming technique. In another study by [48], the fuzzy particle swarm optimization method was used to obtain the optimum location and size for the BESS and they developed a control system to reduce the required battery size.

One study, [49], determined the size of the battery by using the heuristic-based particle swarm optimization technique. In this study, with the help of a novel algorithm, the most suitable location for BESS was determined. In [50], taking into account the uncertain characteristics of renewable energy resources, the optimum location and capacity for the storage system was obtained using the hybrid multiobjective particle swarm optimization method. In [51], researchers developed the optimal operational strategy for the BESS in order to increase the voltage quality of the system and to maintain the quality according to different scenarios by using the distributed energy sources. In [52], a unique control algorithm was proposed in order to increase the efficiency of the network by reducing the power losses and voltage imbalances in the distribution and transmission network with the help of battery storage systems. In the study [53], the optimum location and size were obtained for the BESS by the genetic algorithm and fuzzy logic techniques to reduce the imbalances and power losses in the network caused by the nonlinear load characteristics. M. G. Ippolito [54] applied various optimization strategies on the BESS to minimize losses, electricity generation costs, and greenhouse gas emissions. Among the strategies applied, they found that multiobjective optimization and NSGA-II (non-dominated sorting genetic algorithm II) techniques yield the most successful results.

\subsection{Demand Control}

By modernizing electricity networks it is possible to increase the efficiency of energy generation and usage, reduce the carbon footprint, and make the whole energy network more reliable. Modern power grids give utilities more control capability. This section provides a literature review of the roles of battery storage systems for demand control.

In [55], a composite battery storage system was proposed that included a high energy density battery and a high power density ultracapacitor to maintain balance in energy consumption. G. Hug-Glanzmann in [56] presented a control system that coordinated the use of storage systems, distributed energy sources, traditional electricity generation and loads to mitigate emissions and 
tolerate the uncertain behaviors of renewable energy resources, as well as used the multi-time step optimization method to optimize the control system. In [57], the noncooperative game theory method was used to determine the optimal strategy for each user based on the data from the user's smart meters. In this respect, it is clear that this is a different study than the existing optimization studies. In addition, the data obtained from the algorithm and optimization study were tested in real time. A study by [58] discussed the responses of customers to electricity spot market prices and used linear programming to develop a fast, optimal algorithm system that could be used during the use of storage systems. This study is considered one of the oldest and fundamental studies in the field of demand control.

Longbo Huang et al. [59] developed a low-complex algorithm in order to optimize demand control with battery energy storage systems. The algorithm system presented operated without requiring energy prices, system dynamics, or any statistical data. A study by [60] developed a building automation system that optimized the electricity demand of the consumer with a battery system in Zurich, Switzerland and examined the effect of demand control techniques on the cost of electricity for users in regions with different user habits. In the approach presented in [61], maximum benefit was obtained for both users and the network operator by reaching the network operator's access to the energy storage systems owned by the users. In C. Gouveia's work [62], when a microgrid is in islanded mode, the operating strategies required for BESS are discussed in order to continue the operations stably while taking into account factors such as electric vehicles and load characteristics. In [63], the optimum battery capacity was determined for a power system in Vermont in order to optimize the relationship between the battery system, solar panels, and the grid, taking into account the load characteristics. In order to achieve this, a novel hierarchical algorithm was developed. In [64], with the help of BESS and a model based on mixed-integer programming, an approach was developed to minimize the operation costs of a microgrid and the number of carbon emissions released into the atmosphere. In addition, the method developed was easily applied to the control system of any microgrid. H. M. Soliman and A. Leon-Garcia [65] used two different game theory methods. In the first stage, as a noncooperative player, each user planned strategies to minimize their costs by optimally planning their electricity demand. In the latter, utilities tried to maximize its earnings using the Stackelberg game while users tried to minimize their costs as a group with successful results.

\subsection{Microgrid Energy Management}

Microgrid systems, one of the solutions that emerged to meet the concerns about greenhouse gas emissions causing global warming, are developing rapidly in recent years. Since the role of renewable energy resources in microgrids is vital, energy storage systems are one of the main components of these systems. In this section, a literature review of the roles of battery energy storage systems on energy management in microgrids is given.

In [66], a central energy management system (EMS) has been designed with the help of the heuristic-based multi-stage optimization method, and an energy control system has been designed to provide optimum performance when a microgrid operates in islanded mode. As well, several test protocols have been proposed to analyze the performance of the system and the effects of the relevant parameters. In [67], an energy management system for the microgrid was proposed, where a mixed integer optimization problem based on prediction models is solved for each decision step. In addition, the energy management system determined the online setpoints for each unit and transferred the demand management-based control information to the consumers. The authors of [68] provided a decentralized control architecture based on a real-time, agent-based decision-making mechanism for microgrids. The results obtained were tested separately for islanded mode and grid mode. The presented systems and formulations demonstrated the applicability and success of the decentralized agent-based control for microgrids. H. Kanchev et al. [69] proposed an energy management system with embedded storage units and PV generators, which were divided into two sections as central power management for the microgrid and local power management for the customer. In [70], mixed integer, nonlinear optimization systems, renewable energy generation, storage technologies, electric 
cars, dynamic pricing and demand management are discussed, and an optimization-based energy management solution is presented for a hospital in the Netherlands.

In Q. Jiang's study [71], a novel microgrid energy management system with two different layers of coordinated control approach was proposed. The authors [72] presented a fuzzy logic-based planning system for BESS. When the results obtained were examined, the proposed approach could easily overcome the uncertainties of the parameters which are difficult to predict during the operation of the microgrid. C. Jin and P. K. Ghosh [73] identified the energy planning algorithm where optimum results were obtained by testing the performance of three different planning methods, including real-time energy demand and pricing, day-ahead estimation, and model predictive control methods. In [74], a control architecture consisting of two layers for the control of multiple microgrids was presented and a symmetrical assignment problem based on the naîve auction algorithm was defined and solved in order to provide the balance in the energy market. The data obtained from different scenarios showed that agent-based management is an extremely economical and profitable technique in energy planning. The study by [75] presented a real-time energy management system that aimed to minimize the energy costs of microgrids by optimizing the charge and discharge processes of energy storage systems on a network of distributed microgrids. In [76], an optimal planning strategy was developed using the distributed algorithm technique that optimized the balance between production and consumption in order to reduce the adverse effects of the uncertainty characteristics of renewable energy sources on the power quality of the microgrid.

\subsection{Investment Deferral}

The primary objective of energy distribution planning is undoubtedly a system design which has the qualifications to economically and safely meet the demand growth that occurs over time. In recent years, with the technological development of battery storage systems, we are starting to see a significant increase in their role in distribution and transmission networks. In this section, the role of the BESS in the distribution and transmission networks for the investment deferral are presented.

In C. Mateo's study [77], a cost-benefit analysis was performed in order to meet the peak energy demands with the battery systems in medium voltage level distribution networks. Lastly, the study sets the target cost for battery storage systems in order to become a profitable investment in distribution networks. W. F. Su and S. J. Huang [78] reviewed the cost analysis of a hybrid energy storage system consisting of PV power and BESS for demand-side applications in Southern Taiwan. In addition, various input data and output data were proposed and discussed for three different investment plans. In [79], the amount of distributed energy storage required to delay the capacity upgrades of transmission and distribution networks in New Mexico was evaluated. The authors in [80] proposed a new method for determining the optimum capacity of wind generators and energy storage systems using mixed integer programming and genetic algorithm methods to defer investment in substations. S. Wogrin and D. F. Gayme [81] proposed a DC optimum power flow method for storage portfolio optimization using linear programming methods for the networks with limited transmission infrastructure. As well, [82] aimed to find a suitable location and size for battery storage systems with the help of a genetic algorithm method in order to reduce the weakness that occurs in the power systems over time.

In [83], the authors demonstrated the optimum location and capacity for BESS with the help of a methodology based on a nonlinear multiperiod optimal power flow and shifting algorithm and concluded that the network investments could be postponed. In the report [84], which wasa prepared under the Electricity Storage Systems program of the United States Department of Energy (DOE) and the Sandia National Laboratories (SNL), contributions of energy storage systems for the deferral of the upgrades required in the transmission and distribution networks were discussed from different angles. There were two objectives presented by [85]. First, the network investment deferral function, which includes the growth rate of energy demand and renewable energy penetration, was established. Secondly, the model was then used to formulate an optimization problem that could optimally plan the location, capacity, and charge-discharge profiles of the energy system. This model was implemented 
in a mid-level distribution network in Australia using a general algebraic method. In F. Zhang's study [86], energy storage systems were introduced to reduce the total cost of the network, and their positioning and sizing were determined by the nodal power balance and the load duration curve. The potential of reducing the network's investment costs through the proposed model and BESS was demonstrated by simulated studies in two test systems.

\subsection{Reactive Power Support}

Reactive power support is one of the primary methods for improving the performance of AC power systems. Reactive power support covers a wide range of both system and customer issues, particularly power quality. In this section, various studies about the reactive power support and applications of battery systems are described.

In [87], the authors focused on improving the voltage quality through reactive power support for an active distribution system, by finding the optimum location for the distributed storage system. The required formulations were developed using the mixed integer linear programming method. This paper [88] provided an overview of the challenges of integrating PV power systems and BESS into the power grid. It also examined various operating modes for ancillary services that are provided by battery systems in solar applications. In [89], the researchers proposed an optimal power flow formulation with wind energy and battery storage systems for active and reactive power flow in distribution networks. M. N. Kabir et al. [90] focused on a droop control-based approach that coordinated control of the PV and battery systems in order to address problems such as sudden voltage rise and decrease. In [47], the authors focused on the optimal allocation of distributed storage systems in active distribution networks and defined a multipurpose optimization problem that sought to find the optimal balance between the technical (reactive power support, etc.) and economic goals of the network.

M. Nick et al. [91] focused on the optimal placement and sizing of distributed storage systems to support the voltage quality, reduce power losses, etc. and benefited from genetic algorithm-based formulations for the required optimization procedures. The article by [92] illustrated the optimal planning of the STATCOM and BESS in a network with high levels of PV and wind power integration and [93] was based on the microgrid including different distributed energy sources. The authors modeled a 34 bus microgrid and showed that a reduction of the voltage quality of the microgrid was prevented by determining the optimal strategies for the distributed energy sources. The integration of BESS into a doubly fed induction generator design that was activated for a short time to soften the rapid power changes caused by wind power was discussed in [94]. This storage device was also used to reinforce the DC bus during transients and to increase the generator's low-voltage ride through (LVRT) capacity. The results showed that short-term power swings are effectively reduced and provide superior performance as compared to traditional topologies.

\subsection{Congestion Management}

Electrical energy is transferred from suppliers to consumers through transmission lines. The congestion in the networks occurs when the transmission lines are not sufficient to transmit the energy. In this section, a literature review of the contributions of BESS to congestion management is presented.

The study by [95] provides the optimal planning and timing of battery storage systems for congestion management in power systems that include various renewable energy resources. The storage units were optimally charged and discharged to overcome the uncertainties associated with wind-PV power, as well as to overcome congestions in the transmission lines. The formulations required for the study were performed using the particle swarm optimization method. In [96], an optimal power flow approach for storage systems to overcome congestion problems in a network where renewable energy resources play an essential role was proposed and the feasibility and economic impact analysis of the system are discussed. In [47], the authors focused on the optimal allocation of BESS in distribution networks using mixed integer second-order cone programming to overcome network congestion management problems. M. Nick et al. [97] proposed a multipurpose procedure for 
the optimum location and size of BESS. The proposed procedure minimized the cost of energy from the grid and power losses with congestion management.

In [98], authors provided an optimal plan for locations that require a minimum size for the BESS to reduce uncertainties of renewable energy resources when managing congestion and voltage levels. The work of [99] provided a solution for the optimal placement of the battery storage system in the grid to solve the congestion in transmission lines. The authors of [100], while optimally preparing the energy storage system to maximize its contribution to congestion management, proposed a new real-time optimal distribution algorithm that seeks to generate revenue by taking advantage of the electricity price arbitrage opportunities in the day-ahead electricity market. A. D. Del Rosso and S. W. Eckroad [101] examined the technical feasibility and potential benefits of energy storage systems to increase the efficiency of congestion management in networks serving regions of the United States with vast renewable energy generation assets. In [102], the authors provided a comprehensive analysis of dynamic interactions between wind energy sources and an energy storage system by examining the effects of different methods that reduce the adverse effects of transmission line congestion on the network and the user.

\subsection{Ancillary Services}

Ancillary services help to ensure reliable operation of the electrical transmission and distribution systems. In this section, a brief literature review of the roles of battery storage systems in the field of ancillary services is presented.

In [103], a method was presented based on the PI control principle to determine the optimal size of the battery storage system required for primary frequency control of the microgrid. In [91], a multipurpose procedure for the optimum location and size of energy storage systems was proposed using a procedure that minimizes the cost of energy from the grid by ancillary services such as voltage support and loss reduction. A. Oudalov et al. [104] provided a method for determining the optimum size of the battery energy system to provide primary frequency control and used data based on the historical frequency measurements to determine the minimum capacity possible. P. Mercier et al. [105] proposed the optimum size and operation plan for a battery storage system, which provided spinning reserve services in an isolated network with the help of a novel control algorithm. A study by [87] focused on installing the BESS in optimum locations to maximize the support of storage systems to the voltage control and the optimum planning procedure was carried out using formulations based on mixed integer nonlinear programming. A study by [47] made significant improvements in various issues such as voltage fluctuations and energy losses by finding the optimum location and size for BESS with the help of the mixed integer second-order cone programming technique.

In another study [106], the mechanism for battery systems in the Southern California region allowed the system to test the concept of system stabilization using the output modulation of the power source instead of reactive power modulation. The results of the battery control mechanism and the data recorded in the field tests were presented in the study. The study by [107] relates to load frequency control of a system which is connected using a battery energy storage system and the results showed that the battery storage system can easily meet the immediate requirements of the load demand and provide useful improvements for reducing the peak deviations of frequency. In G. Delille's work [108], a frequency control method was recommended based on dynamic simulations by optimally controlling energy storage systems on the French island of Guadeloupe with high wind and solar power generation. The results showed that if a significant interruption in generation occurs, the fast-acting storage system reduces the adverse effects on the island's dynamic performance. In [109], a new incremental model of the battery system was introduced and combined with the load frequency control of a grid. Computer simulations showed that the battery system was very useful in damping oscillations caused by load disturbances. Finally, optimization of the controller's gain was obtained by the second method of Lyapunov. 


\subsection{Voltage Regulation}

Voltage regulation is one of the most critical challenges in traditional networks. This problem is challenging to cope with especially in modern networks that have a high penetration of renewable energy resources.

J. H. Choi and J. C. Kim [110] proposed an approach to voltage regulation of distribution networks using a multiple line drop compensation (MLDC) voltage regulation method on distributed storage and generator systems. In [111], significant results were obtained regarding voltage regulation of the grid by applying the optimization method generated by the detailed statistical information of the grid to distributed battery and distributed generators. The authors [112] developed a voltage regulation system by utilizing battery systems using the local droop-based control method developed to keep the voltage level stable at the moments when the load level was at the peak and when the photovoltaic generation was at the peak. In V. Khadkikar's study [113], the authors created a hybrid power system consisting of PV power, wind power, and a battery system. In this system, the inverters of the PV power plant successfully regulated the grid voltage by controlling the charging and discharging of the battery system. In [114], the voltage regulation of a low-voltage network with a high amount of PV power using a coordinated control system was successfully performed with a distributed battery system. H. Nazaripouya et al. [115] determined the minimum battery size required to successfully control the voltage regulation based on the location and size information of solar energy using the iterative optimization method. In [49], the authors identified the battery size required for voltage regulation using the heuristic-based particle swarm optimization (PSO) technique.

In [116], authors provided a procedure for determining the optimum size of a battery energy storage system in order to shave the peak demand reached during the day. According to the results obtained, the system was able to quickly provide the necessary voltage supports via the battery. In another study, [52] proposed an energy storage system to reduce voltage imbalances. In the generated energy storage model, a control algorithm was developed and implemented to examine the ability of the battery system to reduce the imbalance in grid voltage levels and reduce losses. The simulation and experimental studies showed that the storage system performed very effectively and reduced voltage imbalance, thus increasing its efficiency. Y. Yang et al. [117] presented an effective size determination strategy for the distributed battery energy storage system in distribution networks with high levels of PV penetration. The primary purpose of the proposed method was to optimize the capacity of the distributed battery system according to the grid characteristics and to obtain cost-benefit analysis for the system when the battery system is involved in ancillary services such as voltage regulation and peak load shaving. In [118], the researchers explored the different strategies that are used to regulate the voltage level of the grid and to control the battery storage unit. Simulations, combined with actual data from a rural area fed from a single-phase network, indicated that the battery system improves the voltage quality of the grid.

\subsection{Load Shifting}

Load shifting control has attracted increasing attention from both researchers and engineers for decades as one of the most impactful methods to control peak load periods. In this section, the studies about the contribution of battery storage systems on load shifting are included.

A study by [119] proposed an optimal working strategy to successfully perform load shifting during peak hours needed in a small/medium-sized network that consists of renewable energy resources and battery systems. In C. Lu's study [120], using an optimization method based on mixed integer programming, the authors minimized the stress of the distribution network and the adverse effects of daily load variation differences in the peak load periods. In [47], they focused on the optimal allocation of battery storage systems in distribution networks using mixed integer second-order cone programming, which aimed to find the optimal balance between the technical problems and economic targets. In [57], I. Atzeni used the noncooperative game theory method to determine the optimal 
strategy for each user based on the data from the user's smart meters and tested the data obtained from the algorithm and optimization study in real time.

H. Fathima's [121] conducted a feasibility study to integrate the battery energy storage system into a power system composed of grid-connected hybrid wind-PV power. The methodology for the battery sizing was based on the bat algorithm and developed to minimize investment costs and losses in the system. In [122], the proposed approach enabled the consumers to dynamically evaluate the battery time and the most suitable time for running the required devices, and thus minimize the cost of daily energy in scenarios characterized by an advanced demand management system. A study by [123] emphasized the optimum sizing methodology and working strategy of a battery storage system that is necessary to shave and shift the load when it reaches the peak level. The size determination methodology was based on maximizing the economic benefits of the customer and the optimum operating strategy of the battery storage system was based on dynamic programming techniques.

\subsection{Energy Arbitrage}

In recent years, with the development of battery technologies the opportunities required for energy arbitrage have started to diversify. It is expected that energy arbitrage solutions will result in significant savings in the energy usage of end users in power networks where already radical changes are taking place. In the first study [124], the effect of 1MW BESS managed by two fuzzy logic controllers on primary control reserve and energy arbitrage services was tested with real metered data from an Italian network. In [125], to maximize the daily operation revenue of a lithium-ion (Li-ion) battery, the authors tested a dynamic battery model based on optimum charging-discharging in an 11 year simulation of Texas region data. In another study [126], optimum management of a distributed battery energy storage system for energy arbitrage under dynamic pricing conditions was presented and the results showed which arbitrage policy is Pareto optimal for value lifetime performance. In [127], a home battery system was optimized using a stochastic dynamic programming model according to four different case studies that were composed of arbitrary, backup energy, regulation, and distribution relief.

In Nottrott's study [128], for a hybrid structure consisting of PV and BESS, peak net load management and demand charge minimization were performed and the optimal energy storage dispatch schedule model was created using linear programming. Furthermore, with the help of energy arbitrage solutions provided by the schedule, a significant increase in the net present value (NPV) of BESS was achieved. In [129], the amount of capacity required to maximize the internal rate of return (IRR) of 14 different energy storage technologies used in arbitrage transactions in the 2008 U.S. electricity market was determined by linear programming. This study [130] proposed an optimal battery management method based on a forward dynamic programming algorithm using a hybrid system consisting of a wind generator and a sodium-nickel chloride battery in energy arbitrage operations. In Wankmüller's study [131], the potential economic losses that could occur in energy arbitrage processes due to the degradation of the batteries used in the grid were investigated. As well, [132] presented a dynamic programming-based approach that optimizes the charging-discharging operations of BESS for energy arbitrage and frequency regulation, taking into account difficult-to-predict variables such as demand, electricity prices, and regulation signals.

\subsection{General Overview}

The references cited in Section 3 are grouped by topics and presented to the reader in Table 3. 
Table 3. General overview of the references cited in Section 3.

\begin{tabular}{cc}
\hline Topics & References \\
\hline Loss reduction & {$[4,40-52]$} \\
Demand control & {$[53-63]$} \\
Microgrid energy management & {$[64-74]$} \\
Investment deferral & {$[75-84]$} \\
Reactive power support & {$[45,85-92]$} \\
Congestion management & {$[45,93-100]$} \\
Ancillary services & {$[45,85,89,101-107]$} \\
Voltage regulation & {$[47,50,108-116]$} \\
Load shifting & {$[45,55,117-121]$} \\
Energy arbitrage & {$[122-130]$} \\
\hline
\end{tabular}

\section{Challenges and Opportunities}

\subsection{Technical Challenges}

The idea of using battery systems in power grids first emerged in the 1980s. Notable examples since the 1980s are the BESS in Berlin, Lausanne, South Korea, Jeju Island, and other small island systems [133-138]. The integration of BESS in the power grid helps to solve many problems of the power grid [139-143]. However, the effect of BESS on the power grid depends directly on the efficiency of the system's connection to the main grid. Different power electronic topologies address these problems. According to the characteristics of the network, the most suitable of these topologies is selected. In addition, the battery systems should respond to issues in the grid on a millisecond timescale. This task is critical because of the stochastic nature of renewable energy resources in modern power grids. If the BESS fail in response time and operational control, large-scale technical and economic losses result for both consumers and utilities. Thus, the control of BESS is the most critical task in grid-scale applications [108,144-148].

Battery systems have started to change the transportation sector in recent years, and the role of electric vehicles (EV) in modern grids will be one of the factors that determine the future. The battery systems of electric vehicles provide a variety of ancillary services to support the network when the power grid is insufficient. However, the complex distribution of EV across the network can cause control problems, and this may lead to frequency and voltage instabilities and overloads on the network during the energy transfer from the vehicle-to-grid (V2G). However, at present, the number of vehicles and battery sizes is not enough to implement this concept in practice [149-153].

Aging is an inevitable process that occurs in all electrochemical devices, including batteries. This process changes the capacity of a device over time. A long-lasting and demanding application results in both performance and capacity reduction of the BESS and affects the economic parameters of business via increased operational and replacement cost [145].

It is notable that there are no significant differences in the lifetime of the most popular battery types used in the grid. According to Table 1, lithium-ion and lead-acid batteries, which are among the two most popular types, have a lifetime of up to 15 years, considering average usage characteristics. Of course, this period is likely to change depending on the circumstances. For example, battery management systems can make progress in extending the battery life by controlling the charging and discharging cycles of the batteries with the help of optimization methods, and new generation approaches such as AI and machine learning.

One of the critical issues for batteries is safety levels. Fortunately, significant improvements have been observed in the safety levels of batteries with recent developments. If a safety comparison is made between the two leading batteries, such as lead-acid and lithium-ion, both lead-acid and lithium-ion batteries have a thermal runaway risk due to their structure. Since lithium-ion batteries have a higher energy density than lead-acid batteries, they may create a riskier situation in terms of safety. 
In the past, lead-acid batteries have been the leading option. However, since they represent the optimal balance between cost, lifetime, safety, and energy density, lithium-ion batteries have become prominent among the BESS approaches in recent years. Lithium-ion batteries have also led to more successful and efficient results, especially in cases where the battery needs to play more frequent roles in the network, such as ancillary services and the huge lithium-ion battery installation in South Australia demonstrates this trend [154,155].

\subsection{Economic Challenges}

The investment cost of storage technologies depends on its location and technical characteristics, and it is essential to determine the benefits of the storage devices to the installation area. The cost calculations of the battery systems start with the chemical material of the battery, and the economic and technical constraints of the fundamental materials have a direct impact on the investment costs of the batteries. Significant progress has been made as a result of efforts to reduce the costs of the materials used in the batteries. However, there are still critical cost and capacity barriers to the use of batteries, and these problems are the most crucial obstacle to the global expansion of batteries. Especially in hybrid power systems, the lifetime of the battery systems is less than the solar panels and wind turbines. Thus, this situation causes an additional cost such as replacement cost [153,156-158].

As mentioned in the technical challenges, even small-scale problems that may arise during the use of utility-scale batteries can cause enormous economic losses for users and the utility in the area where the battery is used.

\subsection{Regulation Challenges}

With the increasing popularity of battery systems, governments and other organizations have begun to make new regulations related to these battery systems. The necessary arrangements for BESS, which have an important role in the transition to renewable energy, are made in parallel with regulations about energy sources such as solar energy and wind energy. One example of a template for these regulations is the Storage Roadmap for California published by the CAISO California Independent System Operator [159].

Various incentive programs are carried out to facilitate large-scale energy storage projects. A notable example for the incentive programs is the $\$ 150$ million Tesla battery system investment in South Australia. As another example, the USA provides a $20 \%$ tax credit for energy storage investments that contribute directly to the electricity grid through 2020 [160]. In Germany, nearly every project that contributes to the generation and storage of electricity through renewable energy resources and storage systems is a feed-in tariff project $[138,161]$.

Inevitably, the number of batteries will increase in the following years. Thus, the potential impact of the chemicals in the battery on the environment is another matter of regulation. Controlling the recycling process of batteries is of importance for preventing potential environmental pollution. The EU and USA have made various serious regulations regarding the recycling of batteries [18].

\subsection{Opportunities}

The intermittent and unpredictable characteristic of renewable energy resources, which are the most effective solution for humanity against climate change, is one of the biggest obstacles to the expansion of RER. In particular, the integration of RER into the grid causes hazardous operational problems, and therefore, RER must work with auxiliary resources. For example, if the power transferred from the RER to the grid is $10 \%$, it is necessary to support the grid from other sources that have a power of $4 \%$ RER's output. Therefore, the integration of battery systems in the grid is importance for solving operational problems of RER. Thanks to the fact that the battery systems are easily installed and contributed at every location, the RER will become more widespread in the coming years $[88,142,143,151,153,162,163]$. 
Batteries shape not only electrical networks but also the transportation sector. With the development of battery technologies, EV have started to replace internal combustion vehicles which has forced the transportation sector to change. Furthermore, through the V2G concept, the EV, which have significant potential in the future, will play an essential role in providing ancillary services to the grid. Thus, there will be significant developments in the fight against climate change as a result of the contributions of the batteries in this area $[149,152,153]$.

Human beings will have a power grid that offers uninterrupted energy in the following years thanks to the responsibilities that the batteries will undertake in an emergency. In addition, individual users who generate and store energy will change their traditional role in the network and become a decentralized seller. In a decentralized system, the role and impact of the monopolies will become insignificant, and thus in the following years, we will have a more independent energy infrastructure.

\section{Energy Storage Applications for Turkish Transmission System Operator (TSO)}

As mentioned in the previous sections, energy storage systems provide many supportive and ancillary services for power networks and ensure the reliability of the networks. In recent years, with the popularity gained by the storage systems, many significant innovations have emerged in this sector. However, the profitability of such a system for real-world applications depends on many factors, such as the share of renewables, the structure of market prices, local constraints of the power system, regulations, etc. In addition, it has to be rigorously assessed and compared to other solutions, such as grid reinforcement, providing frequency regulation with conventional power plants, etc., before implementation in the grid.

\subsection{Frequency Regulation}

Frequency regulation is considered the first task for utility scale BESS applications. Thus, in the future, there are some estimations that may become the Turkish TSO (TEIAS) plan for using battery storage technologies, especially in frequency services. In the case of the rapid reserve requirement, batteries are seen as more successful than conventional power plants and they meet the area control error (ACE) signal criteria with lower capacities.

In this study, the TEIAS planning system data are analyzed. As shown in Figure 6, a renewable energy generation decrease of $935 \mathrm{MW}$ is observed in 15 minutes. In the case of a decrease of $935 \mathrm{MW}$ in generation, the ACE signal criterion could not be ensured in the simulation model, which was created by considering the current secondary frequency structure, as a result of the one-hour analysis for frequency control in the scenario with $20.5 \mathrm{GW}$ wind power and $16.5 \mathrm{GW}$ PV power installed.

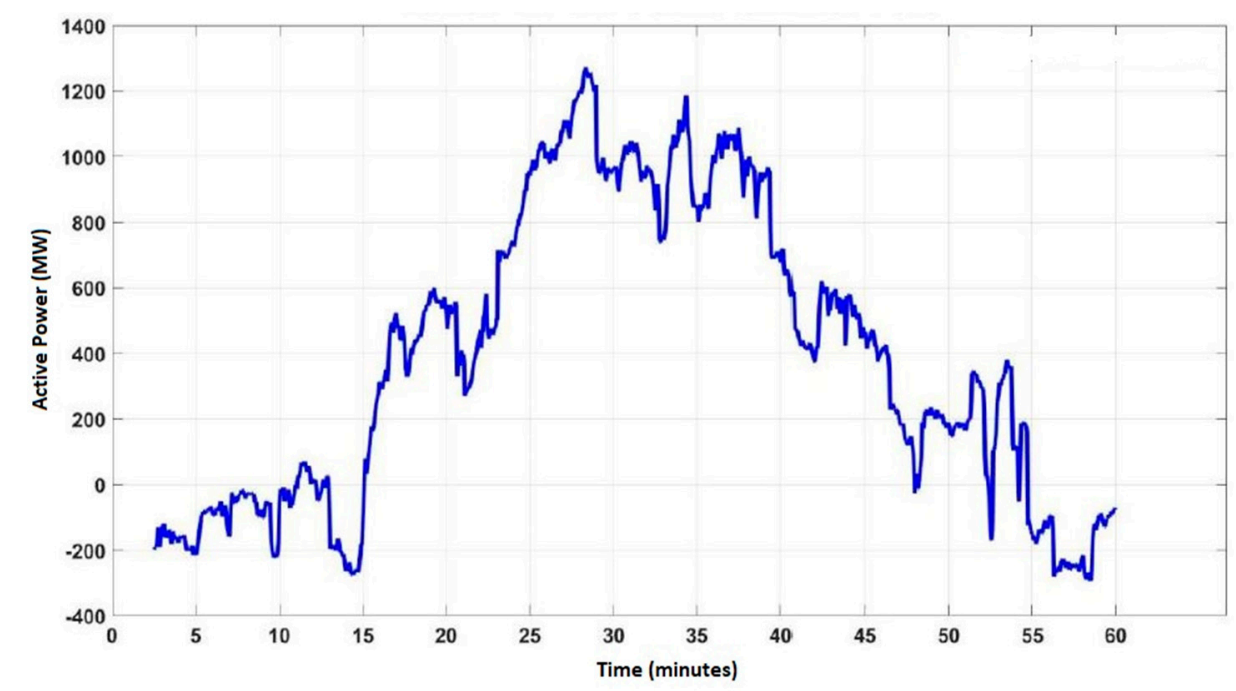

Figure 6. $935 \mathrm{MW}$ decrease in renewable energy generation. 
The reserve portfolio has been changed in order to tolerate the imbalances caused by the decrease in renewable energy generation and to make the secondary frequency control mechanism (SFCM) sufficient. The TEIAS has determined that $900 \mathrm{MW}$ from existing power plants and $100 \mathrm{MW}$ from the lithium-ion battery will be sufficient. Thus, when renewable energy generation began to decrease, a 100 MW BESS in the region starts to discharge its stored power with the help of the energy management system. With this reserve structure, the active power change was reapplied, and the simulation was performed again. The ACE signal criterion, which could not be achieved in the previous case, was provided with a $100 \mathrm{MW}$ battery reserve. The one-hour active output power and energy graph of the lithium-ion battery with 100 MW reserve capacity are shown in Figures 7 and 8.

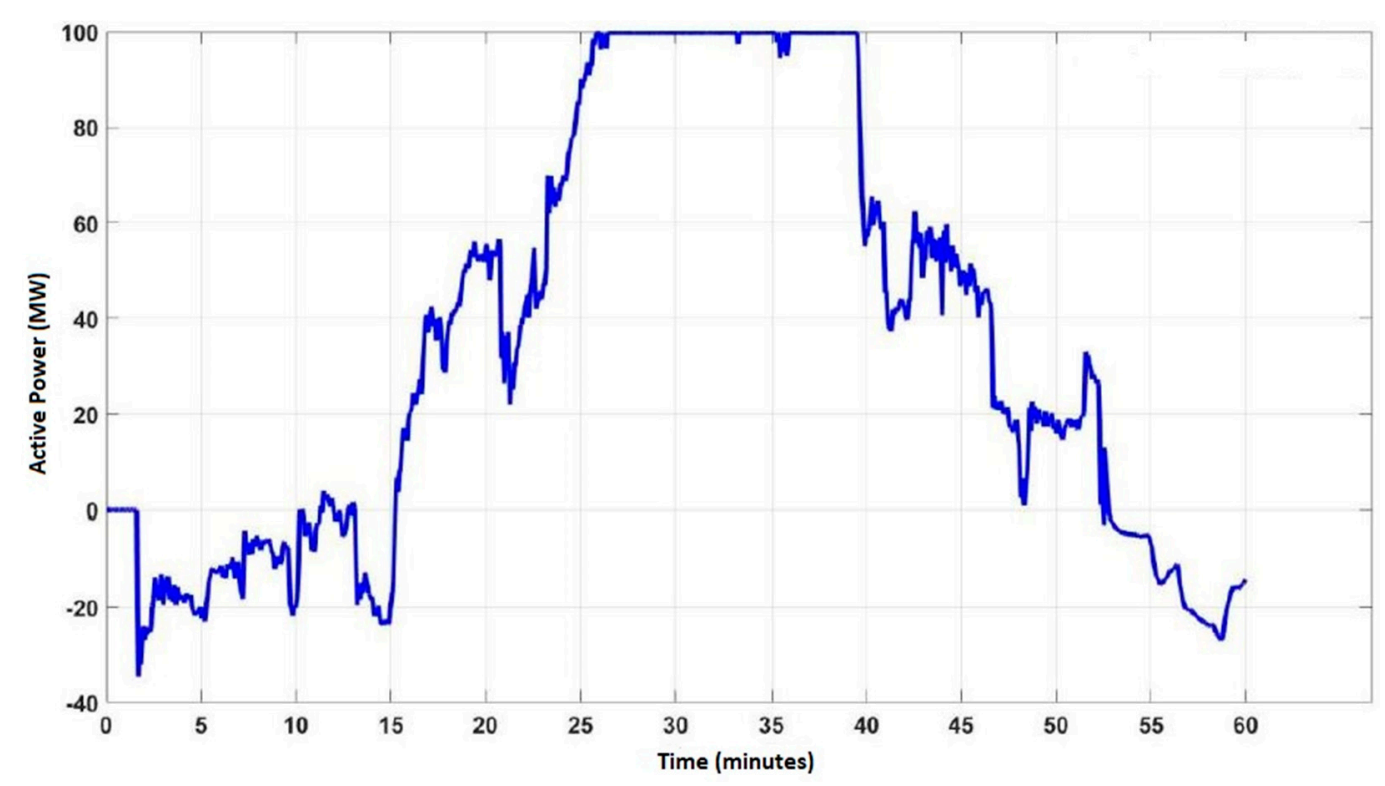

Figure 7. Output power of $100 \mathrm{MW}$ battery.

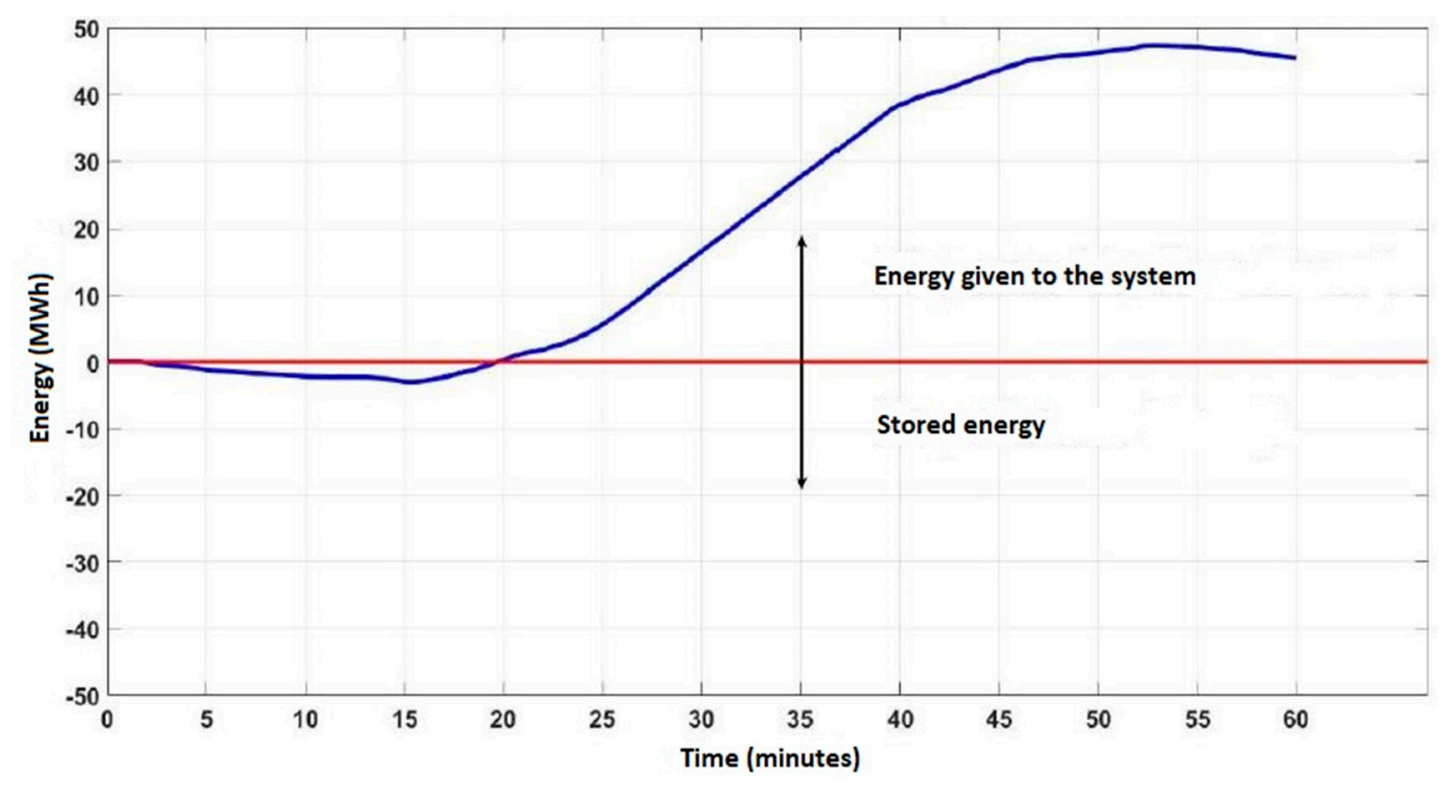

Figure 8. The amount of energy that the $100 \mathrm{MW}$ lithium-ion battery gives to the system and draws from the system.

On the other hand, in order to determine how much reserve is needed for the SFCM to be sufficient without the use of a battery, the reserve amounts of existing plants were increased, and the simulation was performed without including a battery reserve. The required reserve amount is given in Table 4 . 
Table 4. Comparison of required reserve amounts for SFCM.

\begin{tabular}{ccc}
\hline Case & $\begin{array}{c}\text { Sufficient SFCM Reserve with } \\
\text { Existing Power Plants }\end{array}$ & $\begin{array}{c}\text { Sufficient SFCM Reserve with } \\
\text { Existing Power Plants and BESS }\end{array}$ \\
\hline Decrease of 935 MW in generation & $1200 \mathrm{MW}$ & $900+100 \mathrm{MW}$ \\
\hline
\end{tabular}

At this point, it is essential to evaluate whether BESS contributes economically. As shown in Table 3, in the case of the rapid reserve requirement, by updating the reserve portfolio to include BESS, the total reserve amount required for SFCM is reduced.

In such a case, the BESS investment that is based on the SFCM reserve cost and the return on investment has been calculated. In this context, the values used in the calculation are as follows;

The installation cost (converters and battery management systems included) of a lithium-ion battery with an installed size of $100 \mathrm{MW}$ and an energy capacity of $800 \mathrm{MWh}$ is expected to be approximately $\$ 285,000,000$.

- When the SFCM prices obtained from the market management system page of the TEIAS for the period of this study are examined, it is seen that the average SFCM reserve capacity price of 2018 is approximately $90 \mathrm{TL} /$ hour $(\sim 17)$.

- Considering the annual operating capacity of the battery as 0.95 , the annual revenue of the 100 MW battery to be included in the SFCM reserve is calculated as follows:

$$
\begin{gathered}
\text { Annual revenue }=0.95 * 8764 \text { hour } * 100 \mathrm{MW}^{*}\left(\$ 17 /\left(\mathrm{MW}^{*} \text { hour }\right)\right) \\
\text { Annual revenue }=\$ 14,153,860 \\
\text { Operating expense (annual) }=0.02 * \text { investment cost } \\
\text { Operating expense (annual) }=\$ 5,700,000
\end{gathered}
$$

- The cycle efficiency for Li-ion batteries is known to be around 90\% [164]. In addition, the market clearing price has been around $\$ 48$ since 2015.

- It is also assumed that BESS will cycle 300 times in a year. The financial loss due to cycles is calculated as follows:

$$
\begin{gathered}
\text { Financial cycle loss }(\text { annual })=(1-0.90) * 300 * 800 \mathrm{MWh}^{*}(\$ 48 / \mathrm{MWh}) \\
\text { Financial cycle loss }(\text { annual })=\$ 1,152,000
\end{gathered}
$$

Annual profit = annual revenue - operating expense (annual) - financial cycle loss (annual) (7)

$$
\text { Annual profit }=\$ 7,301,860
$$

As a result, if the TEIAS wants to install a $100 \mathrm{MW}$ battery system for their network at current market prices, the annual profit will be $\$ 7,301,860$.

\subsection{Congestion Management}

Another area that the TEIAS will benefit from battery systems is congestion management which is one of the critical issues in the TPN. With the investments made in RER, the increase in seasonal demand and generation of the RER in some regions is vital for the grid characteristics of the TPN. However, the forecast problems of RER still cause curtailments on the use of these resources. The approach to be followed when a congestion issue is encountered in the network is given in Figure 9. 


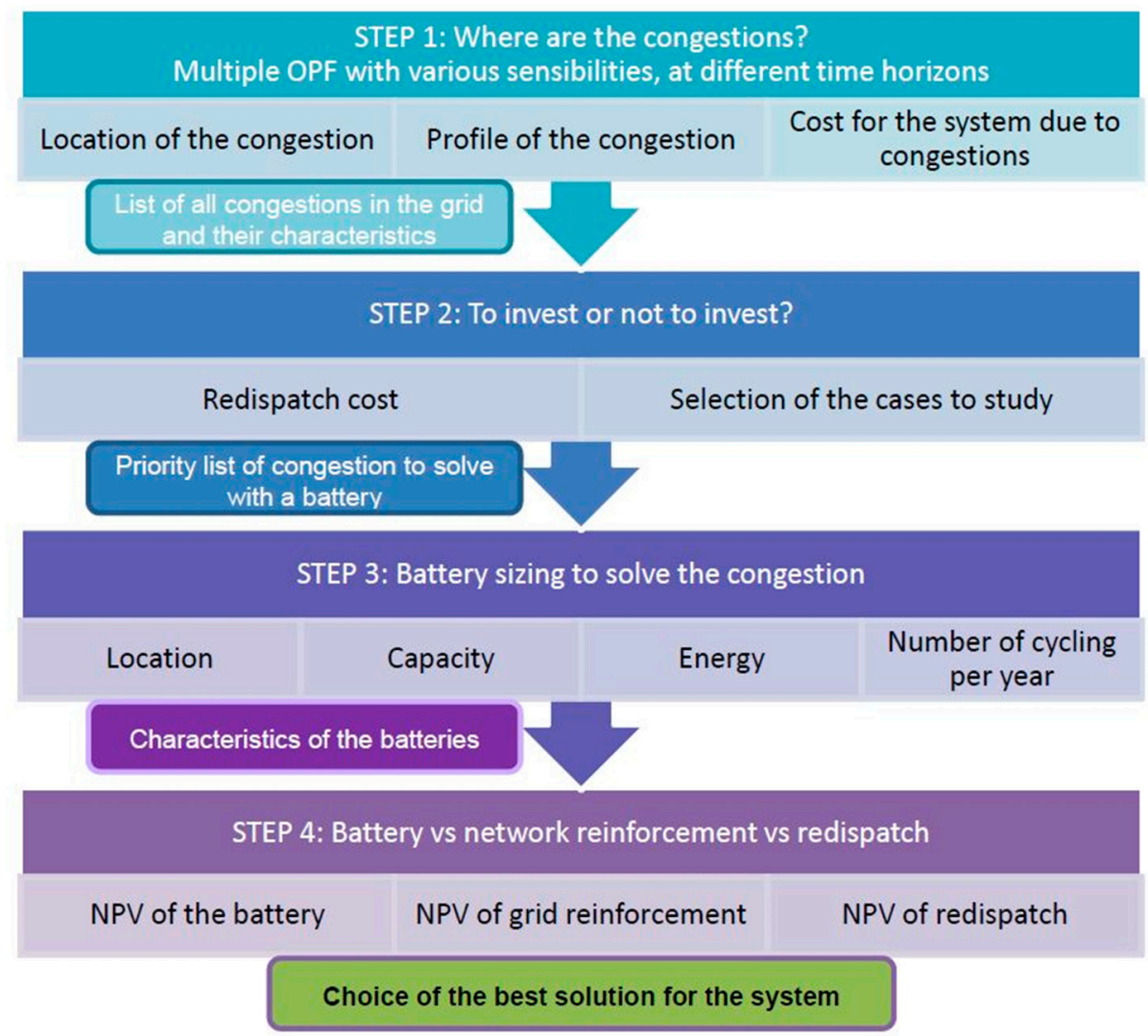

Figure 9. A four-step detailed methodology for the congestion problem.

By checking other countries, especially in Europe, it is seen that most of the countries use energy storage solutions in regions where the demand is stable or decreasing, which is not a part of the large interconnected system. Thus, it seems that the use of energy storage for congestion management may be less efficient than other options for TPN, given the factors such as the structure of the TPN and the cost of the batteries. However, since congestion is a local problem, the TEIAS takes into account mobile storage technologies for the congestion problem. In this way, when the system topology changes within a few years, the TEIAS can easily move BESS to another part of the network on demand according to the congestion conditions in the network. This congestion study deals with three different congestion management issues. It should be noted that this study focuses on a regional congestion problem rather than on transmission lines with a specific location for all cases.

A congested line of $400 \mathrm{kV}$ caused by excessive wind energy generation on the west coast of Turkey is shown in Figure 10. In order to solve this congestion problem, coal power plants in the Western Anatolia region have decreased their generation. On the other hand, hydropower plant and natural gas combined cycle power plant (CCPP) in the Central Anatolia region have increased their generation levels to meet the demand. A possible solution for one of the scenarios, should the TEIAS have a battery system in this area, is that excessive wind generation could be used to charge the batteries. Eventually, batteries could discharge this power to feed the system, and thus the congestion problem would never have occurred in the region. 


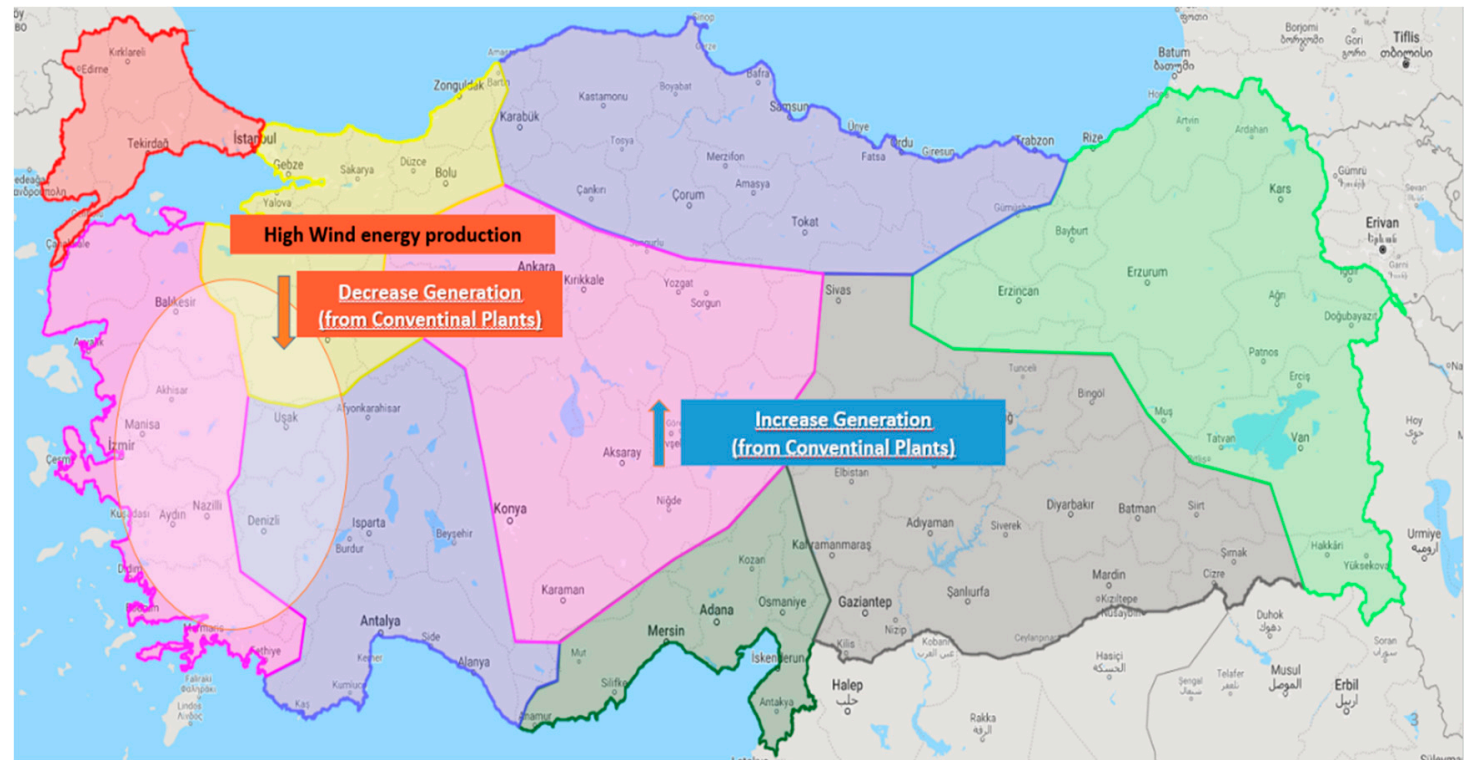

Figure 10. Overloading problems between the East Mediterranean and the West Anatolia region.

The situation in Figure 11 presents the congestion issue in South Turkey due to the agricultural irrigation that causes high demand in summer. The generation of the hydropower plant in this region is very high, so this results in congestions on $154 \mathrm{kV}$ transmission lines of this region. This problem is considered as a regional congestion problem rather than a specific location problem of the transmission line.

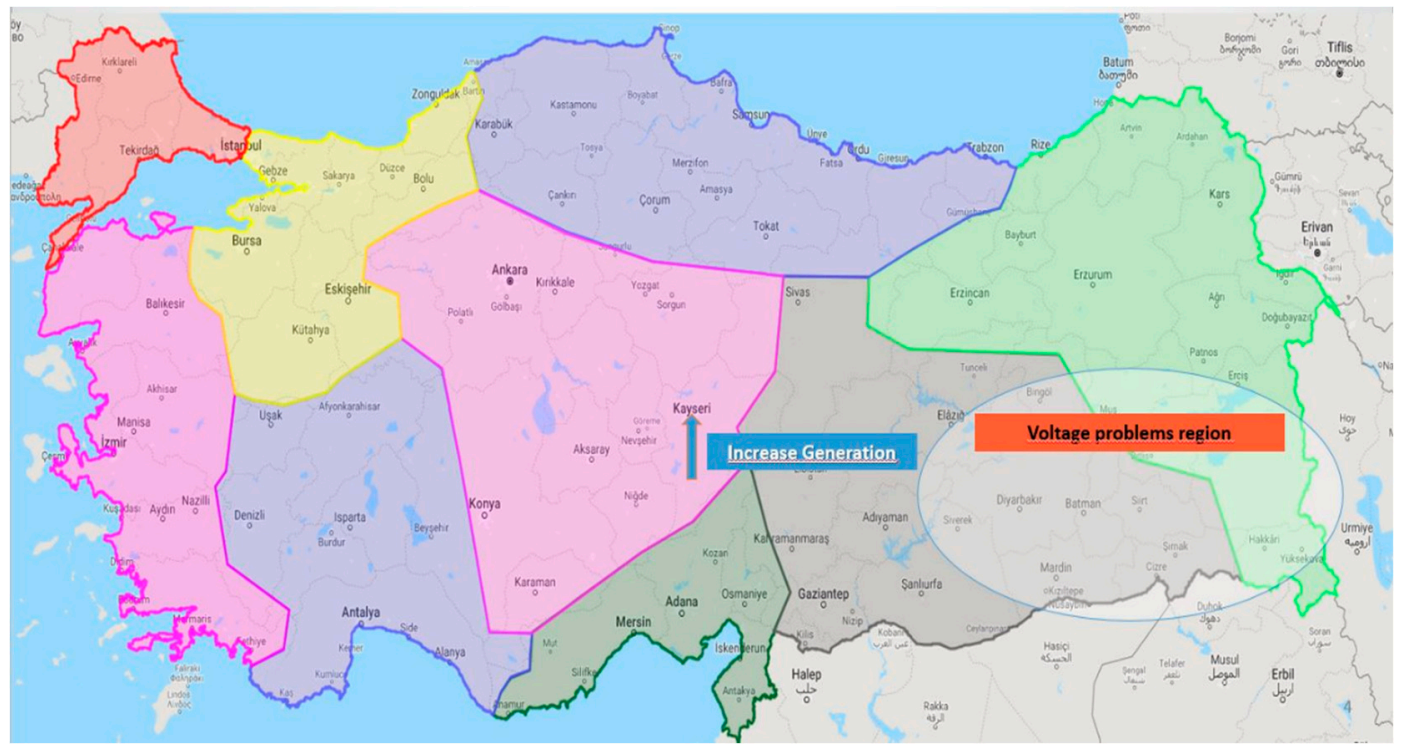

Figure 11. Voltage regulation problems in the region with $154 \mathrm{kV}$ transmission line overloading.

The last case study of the congestion study is represented in Figure 12. Here, the energy generation of the hydroelectric power plant in the Eastern Black Sea region is high, due to low demand in the Eastern Anatolia region and the congestion problem occurs in the region between Eastern and Western Turkey. The flow of a large part of the power to the Northwest Anatolia and Thrace region, where the demand is high, has led to the congestion of the transmission lines in this region. The cost of the congestion in the lines was $60,000 \mathrm{TL} / \mathrm{h}(\$ 1=5 \mathrm{TL})$ for the TEIAS. 


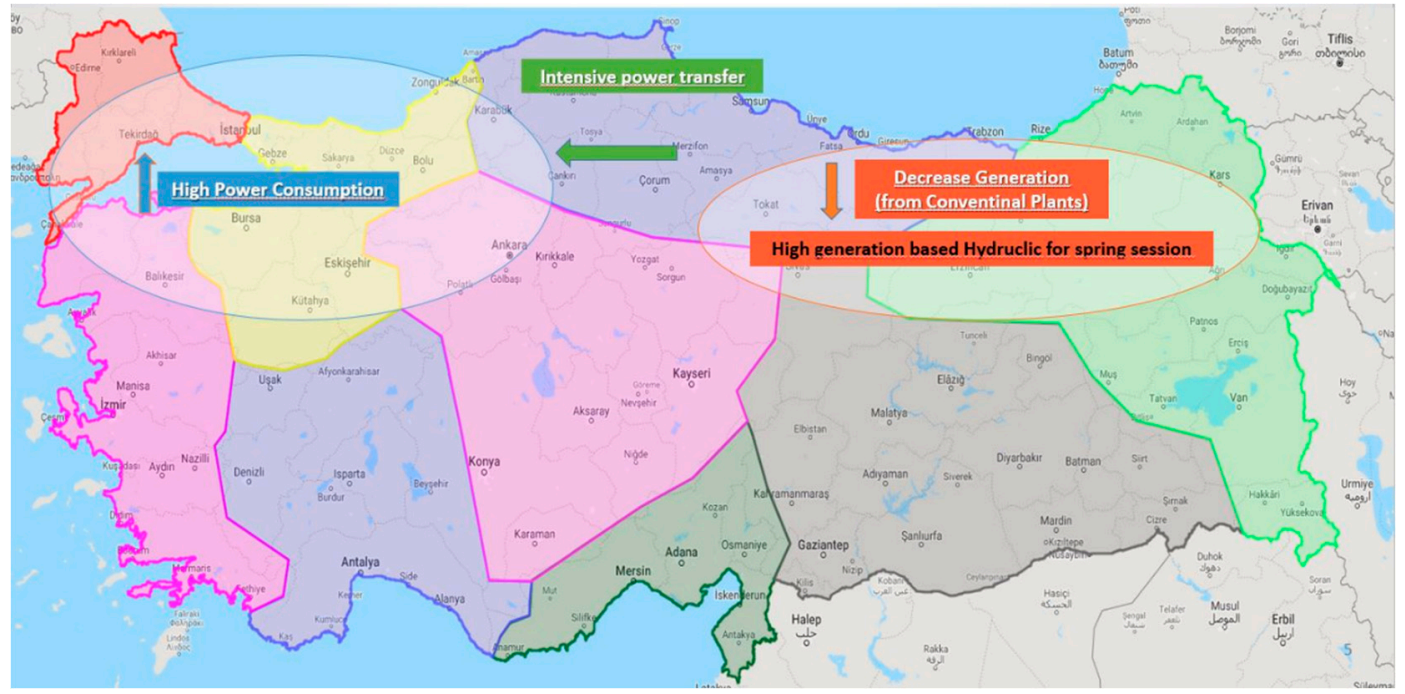

Figure 12. OHL overloading problems in Northern Turkey.

As a result, battery systems are a powerful alternative to congestion problems for system operators. However, operators may decide on the use of battery systems after conducting the feasibility studies required for each zone. The feasibility study given below is carried out based on economic factors. Tables 5 and 6 provide a brief overview of the investments required to solve the congestion problem without using a battery.

Table 5. Standard reinforcement costs for transmission line in Turkey.

\begin{tabular}{ccc}
\hline Voltage Level $\mathbf{( k V )}$ & Characteristics & Cost (per $\mathbf{k m})(\boldsymbol{\epsilon})$ \\
\hline 400 & 3 Bundle 1272 MCM & 122,500 \\
400 & $2 \times 3$ Bundle 1272 MCM & 237,500 \\
\hline
\end{tabular}

Table 6. Standard reinforcement costs for feeder in Turkey.

\begin{tabular}{ccc}
\hline Voltage Level (kV) & Characteristics & Cost (per km) (€) \\
\hline 400 & OHL Feeder & 625,000 \\
\hline
\end{tabular}

The location of the battery depends on the structure of the network. However, it is likely that the battery is directly connected to the bus that is close to the line which suffers from congestion. In order to choose the best connection, locational influence coefficients have to be computed. Those coefficients are also known as the PTDF (power transfer distribution factor). The PTDF is a factor which represents the percentage of change in power flow through network branch $(i-j)$ due to the existence of a new transaction in the system (from bus $\mathrm{X}$ to bus $\mathrm{Y}$ ). This is shown analytically as:

$$
\begin{gathered}
\mathrm{PTDF}=(\text { change in power flow through network branch } i-j \text { due to the transaction } \\
\text { from } X \text { to } Y) /(\text { power of transaction from } X \text { to } Y)
\end{gathered}
$$

In addition, the cost calculation for a BESS investment that can be a solution to the congestion problem in TPN is carried out as follows:

The following assumptions are used for a battery cost:

Cells and pack are $200 \mathrm{k} € / \mathrm{MWh}$ power part (converters, containers, etc.) and $130 \mathrm{k} € / \mathrm{MW}$;

Other costs represent $30 \%$ of the total CAPEX (EMS, engineering, etc.);

Lifetime is 15 years;

OPEX is $2 \%$ of the CAPEX; 
Roundtrip efficiency is $90 \%$;

Cost of redispatch is $100 € / \mathrm{MWh}$;

Duration of the congestion is 1 hour;

Notations for formula (it is assumed that the congestion occurs between the A and B areas);

$P_{-}{ }^{A}(t)$ is the most expensive generator available to decrease its generation on area $\mathrm{A}$ at time $\mathrm{t}$;

$P_{+}{ }^{\mathrm{A}}(t)$ is the cheapest generator available to increase its generation on area $\mathrm{A}$ at time $\mathrm{t}$;

$\mathrm{C}_{-}{ }^{\mathrm{A}}(t)$ and $\mathrm{C}_{+}{ }^{\mathrm{A}}(t)$ are their associated costs;

$P_{-}{ }^{\mathrm{B}}(t), P_{+}{ }^{\mathrm{B}}(t), \mathrm{C}_{-}{ }^{\mathrm{B}}(t)$ and $\mathrm{C}_{+}{ }^{\mathrm{B}}(t)$ have the same definitions, respectively, for area $\mathrm{B}$;

Pcong is the amplitude of the congestion.

Total cost of congestion management $=$ cost of the battery + residual cost of redispatch

Residual cost of redispatch $=$ cost with redispatch $(t)-$ cost with optimal dispatch $(t)$

Cost with optimal dispatch $(t)=P_{-}{ }^{\mathrm{A}}(t) \cdot \mathrm{C}_{-}{ }^{\mathrm{A}}(t)+P_{+}{ }^{\mathrm{A}}(t) \cdot \mathrm{C}_{+}{ }^{\mathrm{A}}(t)+P_{-}{ }^{\mathrm{B}}(t) \cdot \mathrm{C}_{-}{ }^{\mathrm{B}}(t)+P_{+}{ }^{\mathrm{B}}(t) \cdot \mathrm{C}_{+}{ }^{\mathrm{B}}(t)$

Cost with redispatch $(t)=\left(P_{-}{ }^{\mathrm{A}}(t)-P\right.$ cong $) \cdot \mathrm{C}_{-}{ }^{\mathrm{A}}(t)+P_{+}{ }^{\mathrm{A}}(t) \cdot \mathrm{C}_{+}{ }^{\mathrm{A}}(t)+P_{-}{ }^{\mathrm{B}}(t) \cdot \mathrm{C}_{-}{ }^{\mathrm{B}}(t)+$

$$
\left(P_{+}{ }^{\mathrm{B}}(t)+\text { Pcong }\right) \cdot \mathrm{C}_{+}{ }^{\mathrm{B}}(t)
$$

Figure 13 represents the result. The annualized cost of a battery (including losses and OPEX) is represented on the $5 \mathrm{MW}$ vertical line. The $5 \mathrm{MW}$ battery is considered to fully solve the congestions of $5 \mathrm{MW}$ and contribute to solving the congestions greater than $5 \mathrm{MW}$. The residual costs of redispatch are decreasing since the bigger the battery the less redispatch is needed. The $5 \mathrm{MW}$ redispatch cost is not zero since some residual redispatch will be mandatory to solve congestion higher than $5 \mathrm{MW}$.

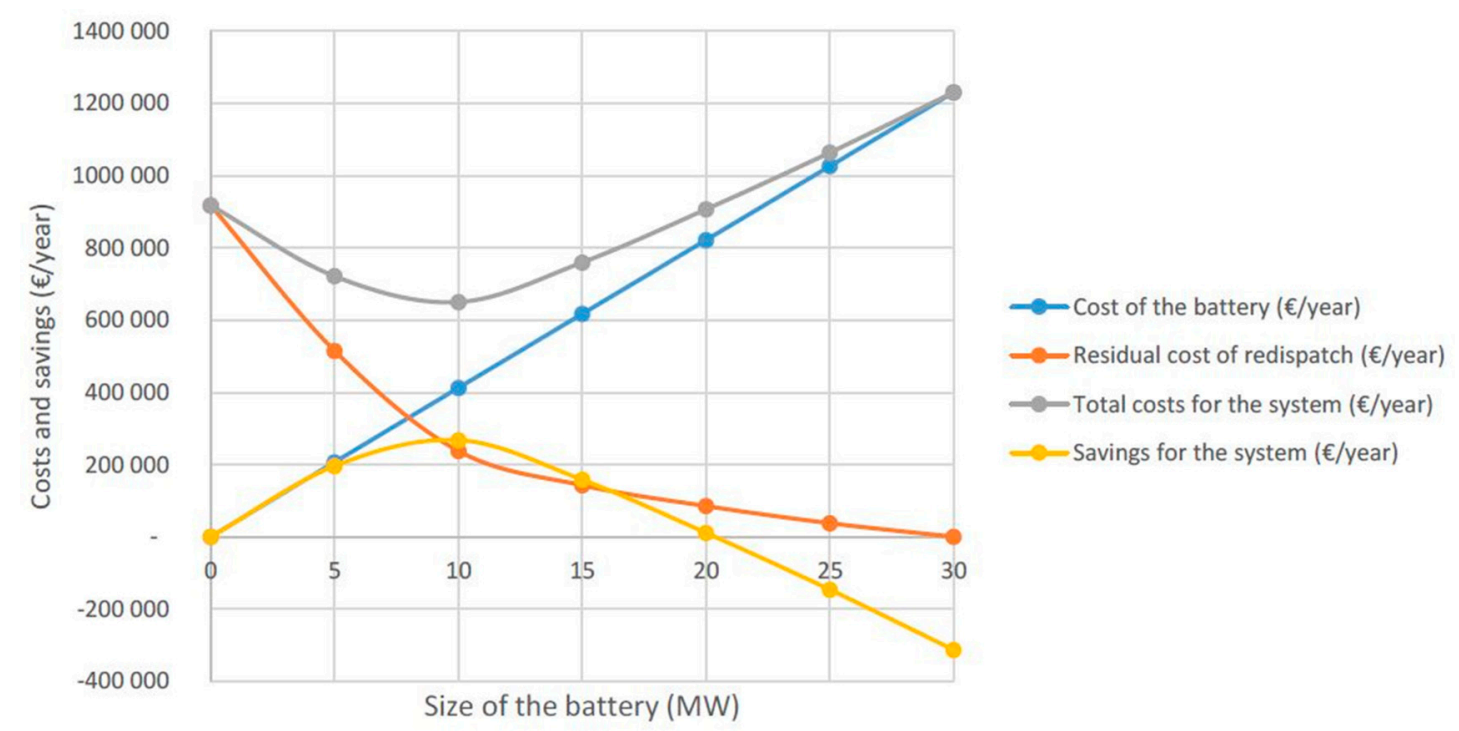

Figure 13. The optimum battery size required to solve a $5 \mathrm{MW}$ congestion problem.

This method aimed at minimizing the cost of congestion management for the system. This is be done by considering the minimum point of the grey curve which is the total costs of the system. According to the results, the use of batteries with a capacity of 5 to $15 \mathrm{MW}$ to solve the congestion problem generates savings for the system as compared with redispatch. A $20 \mathrm{MW}$ battery or larger sized battery is not economically logical. The 20 MW battery solution presents a congestion problem, and therefore it is not enough to choose this battery system for the network. As a result of the simulations, the optimum battery size required for this network structure should be $10 \mathrm{MW}$. 


\subsection{Energy Arbitrage}

It is also considered that the battery storage is efficient on energy arbitrage in specific configurations. The TEIAS assesses the value of this service by considering the spread between the highest and lowest points of the curve of the marginal costs of the TPN and comparing it to the standard energy efficiency of the BESS. Since this service is delivered by utilities or independent power producers (IPP) and not by a TSO, solely, the results of a rough assessment made in order to estimate the potential development of batteries for energy arbitrage services in Turkey is given.

The current Turkish price spread, which is the leading indicator to assess arbitrage profitability, is around $30 € / \mathrm{MWh}$, and only covers $12 \%$ of the annuities of a battery system. Thus, according to the current prices, it is not cost efficient to deliver arbitrage with a battery in Turkey. Figure 14 gives the details of revenues on Turkish day-ahead market

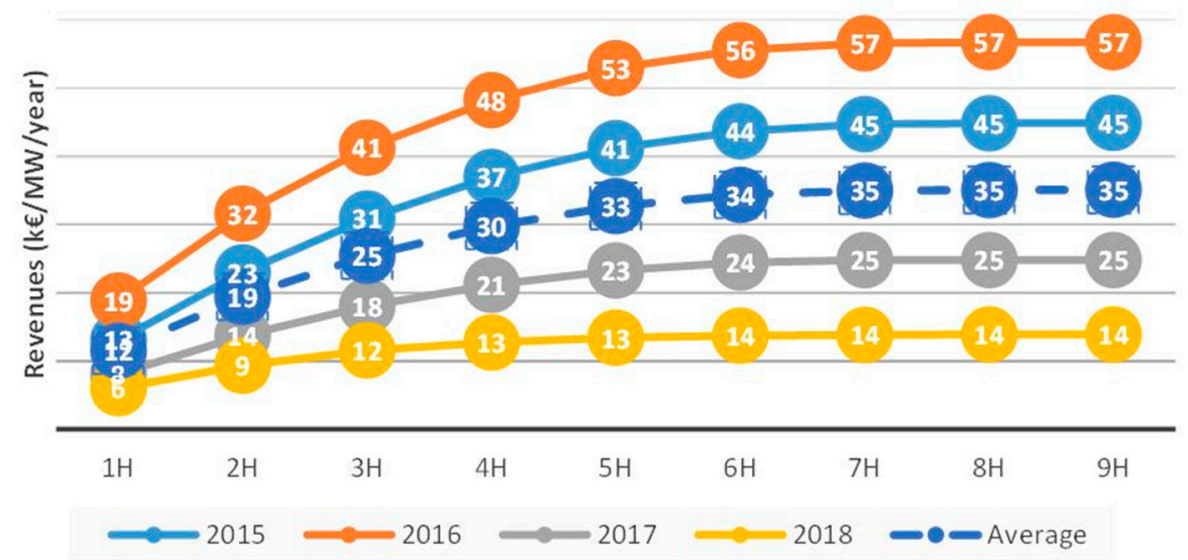

Figure 14. Revenues for a BESS on Turkish day-ahead market.

Even if important spreads were reached in the future, the cannibalization effect would highly limit the development of the relevant volume. Therefore, it is unlikely that a profitable business emerges for arbitrage in the next decade, even with high renewable energy integration. Figure 15 shows the necessary spreads to make arbitrage profitable with BESS in Turkey.

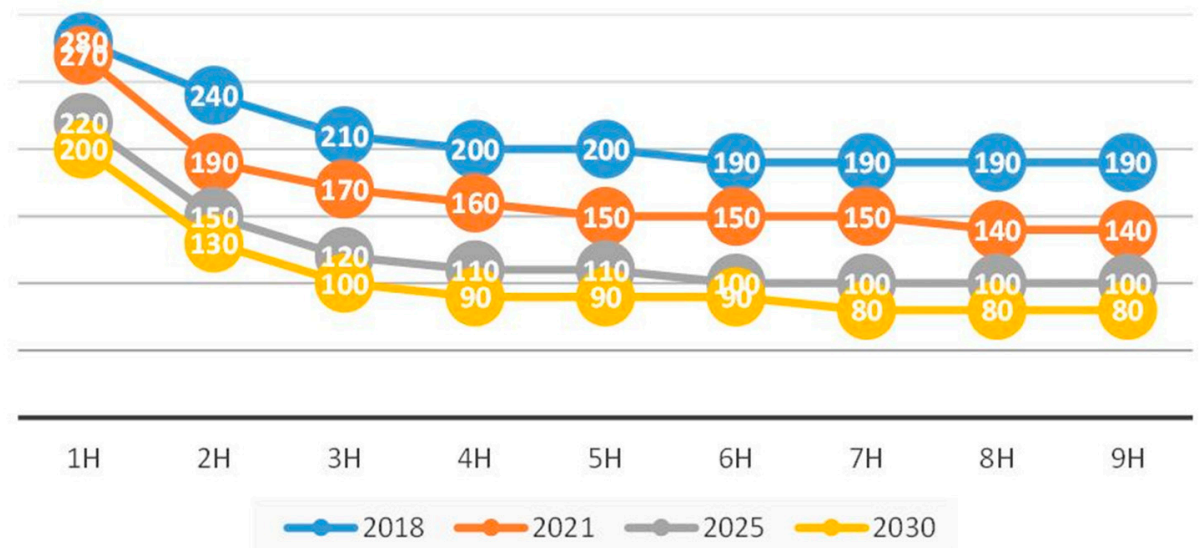

Figure 15. The necessary spreads to make arbitrage profitable with BESS in Turkey.

A very high share of renewables would be necessary to lower prices to less than $10 € / \mathrm{MWh}$ four hours a day. Even in that case, the spreads of the above figure would correspond to peak prices higher than $100 € /$ MWh during four hours each day (17\% of the time). BESS could be profitable after 2025 in Turkey only with spreads greater than $\$ 100$ per MWh on average.

The prices between January 1, 2015 and May 27, 2018 are shown in Figure 16. 


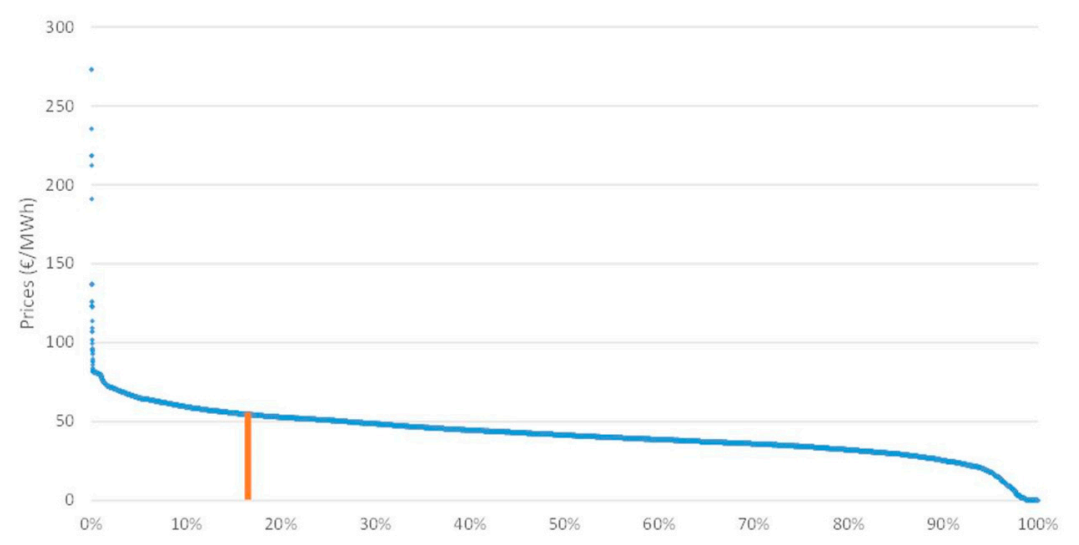

Figure 16. Power market prices between January 1, 2015 and May 27, 2018 in Turkey.

With a simplistic approach, the peak prices four hours a day were higher than $54.4 € / \mathrm{MWh}$. This means the prices of peak power plants should double to make arbitrage profitable, even by 2030, which seems quite unrealistic. Even in this case, it may be more cost efficient to build pumped hydro storage, if possible. Thus, without additional value, a battery providing arbitrage is not profitable for TPN in the next ten years.

\section{Conclusions}

The 21st century became the century when humanity has been experiencing the fastest transformations and changes in the history of civilization. These changes inevitably began to influence and shape traditional power systems. Not only technological developments but also vital problems, such as climate change, manipulate the future of power systems. As a result of all these changes and problems, new and sustainable solutions, such as renewable energy sources, have started to be implemented in the power grids. However, the stochastic characteristics of RER require auxiliary systems for such resources. Storage systems get involved at this point and ensure that the energy supplied from these sources is a continuous and sustainable solution. Especially for utilities and customers, among all storage solutions, the one receiving the most attention is the battery energy storage systems. Since these technologies still have to overcome some issues, utility-scale applications are not yet at the desired level. However, after solving some of the problems that prevent the popularization of the BESS, they will not only eliminate the deficiencies of the RER but will also provide many ancillary services for the networks such as frequency support and voltage regulation congestion management.

This literature review focuses on battery energy storage systems that have the most significant potential for power networks. Technical details of popular battery technologies and a compilation of the methods used to obtain critical information required for the installation of the BESS, such as location, size, and control, are presented to provide solutions to the problems of power networks. In addition, the existing challenges of the BESS and the opportunities they may create in the future are mentioned.

Lastly, how the results of real-world applications on the TEIAS, which is the transmission system operator of TPN, have benefited from BESS as a solution for the problems in the network are described.

Author Contributions: The authors have equally contributed to the writing of the manuscript.

Funding: This research received no external funding.

Conflicts of Interest: The authors declare no conflict of interest. 


\section{References}

1. United States Environmental Protection Agency (EPA). Sources of Greenhouse Gas Emissions. Available online: https://www.epa.gov/ghgemissions/sources-greenhouse-gas-emissions (accessed on 27 March 2019).

2. Kocer, M.C.; Yoldas, Y.; Goren, S.; Onen, A.; Alan, I.; Al-Agtash, S.; Azzopardi, B.; Martensen, N.; Martinez-Ramos, J.L.; Tzovaras, D.; et al. Cloud Induced PV Impact on Voltage Profiles for Real Microgrids. In Proceedings of the 2018 5th International Symposium on Environment-Friendly Energies and Applications (EFEA), Rome, Italy, 24-26 September 2018; pp. 1-6.

3. Yoldaş, Y.; Önen, A.; Muyeen, S.M.; Vasilakos, A.V.; Alan, İ. Enhancing smart grid with microgrids: Challenges and opportunities. Renew. Sustain. Energy Rev. 2017, 72, 205-214. [CrossRef]

4. Abbey, C.; Joós, G. A stochastic optimization approach to rating of energy storage systems in wind-diesel isolated grids. IEEE Trans. Power Syst. 2009, 24, 418-426. [CrossRef]

5. Divya, K.C.; Østergaard, J. Battery energy storage technology for power systems-An overview. Electr. Power Syst. Res. 2009, 79, 511-520. [CrossRef]

6. Hidalgo-Leon, R.; Siguenza, D.; Sanchez, C.; Leon, J.; Jacome-Ruiz, P.; Wu, J.; Ortiz, D. A survey of battery energy storage system (BESS), applications and environmental impacts in power systems. In Proceedings of the 2017 IEEE Second Ecuador Technical Chapters Meeting (ETCM), Salinas, Ecuador, 16-20 October 2017; pp. 1-6.

7. Nadeem, F.; Hussain, S.M.S.; Tiwari, P.K.; Goswami, A.K.; Ustun, T.S. Comparative Review of Energy Storage Systems, Their Roles, and Impacts on Future Power Systems. IEEE Access 2019, 7, 4555-4585. [CrossRef]

8. Leadbetter, J.; Swan, L. Battery storage system for residential electricity peak demand shaving. Energy Build. 2012, 55, 685-692. [CrossRef]

9. Yang, M.; Hou, J. Membranes in lithium ion batteries. Membranes 2012, 2, 367-383. [CrossRef] [PubMed]

10. Sasaki, T.; Ukyo, Y.; Novák, P. Memory effect in a lithium-ion battery. Nat. Mater. 2013, 12, 569-575. [CrossRef]

11. Battery University. How to Prolong Lithium-Based Batteries. Available online: https://batteryuniversity.com/ learn/article/how_to_prolong_lithium_based_batteries (accessed on 3 April 2019).

12. Sony. Lithium Ion Rechargeable Batteries Technical Handbook. Available online: https://www.scribd.com/ document/128610183/Technical-Handbook-Lithium-Ion-Rechargeable-Batteries-Sony-Corp\# (accessed on 3 July 2019).

13. Evolving Energy. Lithium-ion Battery Overview. Available online: http://www.evolvingenergy.com.au/ uploads/2/9/8/5/29857561/evolving_energy_-_lithium-ion_battery_technology_explained.pdf (accessed on 3 July 2019).

14. Dong, X.; Guo, Z.; Guo, Z.; Wang, Y.; Xia, Y. Organic Batteries Operated at $-70{ }^{\circ}$ C. Joule 2018, 2, $902-913$. [CrossRef]

15. Newz Base 2019-2025 Global and China Redox Flow Battery Market by Manufacturers-Sumitomo Electric, Dalian Rongke Power, UniEnergy Technologies | Newz Base. Available online: https://newzbase.com/2019-2025-global-and-china-redox-flow-battery-market-by-manufacturerssumitomo-electric-dalian-rongke-power-unienergy-technologies/ (accessed on 2 April 2019).

16. Uhrig, M.; Koenig, S.; Suriyah, M.R.; Leibfried, T. Lithium-based vs. Vanadium Redox Flow Batteries-A Comparison for Home Storage Systems. Energy Procedia 2016, 99, 35-43. [CrossRef]

17. Alotto, P.; Guarnieri, M.; Moro, F.; Stella, A. Redox Flow Batteries for large scale energy storage. In Proceedings of the 2012 IEEE International Energy Conference and Exhibition (Energycon), Florence, Italy, 9-12 September 2012; pp. 293-298.

18. May, G.J.; Davidson, A.; Monahov, B. Lead batteries for utility energy storage: A review. J. Energy Storage 2018, 15, 145-157. [CrossRef]

19. DeCicco, J.; Kliesch, J.; American Council for an Energy-Efficient Economy. ACEEE's Green Book: The Environmental Guide to Cars and Trucks, Model Year 2001; American Council for an Energy Efficient Economy: Washington, DC, USA, 2001; ISBN 0918249457.

20. Power Sonic Corporation. Technical Manual Sealed Lead-Acid Batteries; Power Sonic Corporation: San Diego, CA, USA, 2011.

21. Skyllas-Kazacos, M. Electro-chemical energy storage technologies for wind energy systems. Stand Alone Hybrid Wind Energy Syst. 2010, 323-365. [CrossRef] 
22. Chemistry LibreTexts 17.5: Batteries and Fuel Cells. Available online: https:/chem.libretexts.org/ Bookshelves/General_Chemistry/Book\%3A_Chemistry_(OpenSTAX)/17\%3A_Electrochemistry/17.5\%3A_ Batteries_and_Fuel_Cells (accessed on 2 April 2019).

23. Kurzweil, P.; Garche, J. Overview of batteries for future automobiles. Lead Acid Batter. Futur. Automob. 2017, 27-96. [CrossRef]

24. Power Electronics NiCd Battery Still Runs after 28 Years. Available online: https://www.powerelectronics. com/news/nicd-battery-still-runs-after-28-years (accessed on 3 April 2019).

25. European Parliament. MEPs Ban Cadmium from Power Tool Batteries and Mercury from Button Cells | News | European Parliament. Available online: http://www.europarl.europa.eu/news/en/pressroom/20131004IPR21519/meps-ban-cadmium-from-power-tool-batteries-and-mercury-from-button-cells (accessed on 3 April 2019).

26. Linden, D.; Reddy, T.B. Handbook of Batteries; McGraw-Hill: New York, NY, USA, 2002; ISBN 0071359788.

27. Breeze, P. Power System Energy Storage Technologies. In Power. Generation Technologies, 2nd ed.; Elsevier Ltd.: Oxford, UK; Boston, MA, USA, 2014; pp. 195-221.

28. Rajagopalan, R.; Balakrishnan, A. Innovations in Engineered Porous Materials for Energy Generation and Storage Applications; CRC Press: Boca Raton, FL, USA, 2018; ISBN 1138739022.

29. IEC. Electrical Energy Storage Executive Summary; IEC: Geneva, Switzerland, 2011.

30. MIT. News Extending the Life of Low-Cost, Compact, Lightweight Batteries. Available online: http: //news.mit.edu/2018/metal-air-batteries-extending-life-1108 (accessed on 3 April 2019).

31. Inverse Zinc-Air Batteries Research Could be a Game-Changer for Consumer Tech. Available online: https://www.inverse.com/article/35564-zinc-air-battery-engineering-breakthrough-lithium-ion (accessed on 3 April 2019).

32. Cheng, F.; Chen, J. Metal-air batteries: From oxygen reduction electrochemistry to cathode catalysts. Chem. Soc. Rev. 2012, 41, 2172-2192. [CrossRef] [PubMed]

33. Chen, H.; Cong, T.N.; Yang, W.; Tan, C.; Li, Y.; Ding, Y. Progress in electrical energy storage system: A critical review. Prog. Nat. Sci. 2009, 19, 291-312. [CrossRef]

34. Ali, A.B.M.S. Smart grids: Opportunities, developments, and trends. Green Energy Technol. 2013. [CrossRef]

35. Luo, X.; Wang, J.; Dooner, M.; Clarke, J. Overview of current development in electrical energy storage technologies and the application potential in power system operation. Appl. Energy 2015, 137, 511-536. [CrossRef]

36. Evans, A.; Strezov, V.; Evans, T.J. Assessment of utility energy storage options for increased renewable energy penetration. Renew. Sustain. Energy Rev. 2012, 16, 4141-4147. [CrossRef]

37. Mahlia, T.M.I.; Saktisahdan, T.J.; Jannifar, A.; Hasan, M.H.; Matseelar, H.S.C. A review of available methods and development on energy storage; Technology update. Renew. Sustain. Energy Rev. 2014, 33, 532-545. [CrossRef]

38. Koohi-Kamali, S.; Tyagi, V.V.; Rahim, N.A.; Panwar, N.L.; Mokhlis, H. Emergence of energy storage technologies as the solution for reliable operation of smart power systems: A review. Renew. Sustain. Energy Rev. 2013, 25, 135-165. [CrossRef]

39. Cavanagh, K.; Ward, J.K.; Behrens, S.; Bhatt, A.I.; Ratnam, E.L.; Oliver, E.; Hayward, J. Electrical Energy Storage: Technology Overview and Applications; CSIRO: Canberra, Australia, 2015.

40. Lam, L.T.; Louey, R. Development of ultra-battery for hybrid-electric vehicle applications. J. Power Sources 2006, 158, 1140-1148. [CrossRef]

41. Kaldellis, J.K.; Zafirakis, D.; Kavadias, K. Techno-economic comparison of energy storage systems for island autonomous electrical networks. Renew. Sustain. Energy Rev. 2009, 13, 378-392. [CrossRef]

42. Hung, D.Q.; Mithulananthan, N. Community Energy Storage and Capacitor Allocation in Distribution Systems. In Proceedings of the 21st Australas. Univ. Power Eng. Conf. (AUPEC), Brisbane, QLD, Australia, 25-28 September 2011.

43. Zidar, M.; Capuder, T.; Georgilakis, P.; Škrlec, D. Convex AC Optimal Power Flow Method for Definition of Size and Location of Battery Storage Systems in the Distribution Grid. In Proceedings of the 9th Conference on Sustainable Development of Energy, Water and Environment Systems, Istanbul, Turkey, 20-27 September 2014. 
44. Abbey, C.; Joos, G. Coordination of distributed storage with wind energy in a rural distribution system. In Proceedings of the Conference Record-IAS Annual Meeting (IEEE Industry Applications Society), New Orleans, LA, USA, 23-27 September 2007.

45. Funabashi, T.; Saber, A.Y.; Toyama, H.; Senjyu, T.; Chakraborty, S. Determination methodology for optimising the energy storage size for power system. IET Gener. Transm. Distrib. 2009, 3, 987-999.

46. Xiao, J.; Bai, L.; Zhang, Z.; Liang, H. Determination of the optimal installation site and capacity of battery energy storage system in distribution network integrated with distributed generation. IET Gener. Transm. Distrib. 2016, 10, 601-607. [CrossRef]

47. Nick, M.; Cherkaoui, R.; Paolone, M. Optimal allocation of dispersed energy storage systems in active distribution networks for energy balance and grid support. IEEE Trans. Power Syst. 2014, 29, 2300-2310. [CrossRef]

48. Zheng, Y.; Dong, Z.Y.; Luo, F.J.; Meng, K.; Qiu, J.; Wong, K.P. Optimal allocation of energy storage system for risk mitigation of discos with high renewable penetrations. IEEE Trans. Power Syst. 2014, 29, 212-220. [CrossRef]

49. Karanki, S.B.; Xu, D. Optimal capacity and placement of battery energy storage systems for integrating renewable energy sources in distribution system. In Proceedings of the 2016 National Power Systems Conference (NPSC), Bhubaneswar, India, 19-21 December 2016; pp. 1-6.

50. Wen, S.; Lan, H.; Fu, Q.; Yu, D.C.; Zhang, L. Economic allocation for energy storage system considering wind power distribution. IEEE Trans. Power Syst. 2015, 30, 644-652. [CrossRef]

51. Kashem, M.A.; Ledwich, G. Energy requirement for distributed energy resources with battery energy storage for voltage support in three-phase distribution lines. Electr. Power Syst. Res. 2007, 77, 10-23. [CrossRef]

52. Chua, K.H.; Lim, Y.S.; Taylor, P.; Morris, S.; Wong, J. Energy storage system for mitigating voltage unbalance on low-voltage networks with photovoltaic systems. IEEE Trans. Power Deliv. 2012, 27, 1783-1790. [CrossRef]

53. Ladjavardi, M.; Masoum, M.A.S. Genetically optimized fuzzy placement and sizing of capacitor banks in distorted distribution networks. IEEE Trans. Power Deliv. 2008, 23, 449-456. [CrossRef]

54. Ippolito, M.G.; Di Silvestre, M.L.; Riva Sanseverino, E.; Zizzo, G.; Graditi, G. Multi-objective optimized management of electrical energy storage systems in an islanded network with renewable energy sources under different design scenarios. Energy 2014, 64, 648-662. [CrossRef]

55. Zhou, H.; Bhattacharya, T.; Tran, D.; Siew, T.S.T.; Khambadkone, A.M. Composite energy storage system involving battery and ultracapacitor with dynamic energy management in microgrid applications. IEEE Trans. Power Electron. 2011, 26, 923-930. [CrossRef]

56. Hug-Glanzmann, G. Coordination of intermittent generation with storage, demand control and conventional energy sources. In Proceedings of the 2010 IREP Symposium-Bulk Power System Dynamics and Control-VIII, IREP2010, Rio de Janeiro, Brazil, 1-6 August 2010.

57. Atzeni, I.; Ordóñez, L.G.; Scutari, G.; Palomar, D.P.; Fonollosa, J.R. Demand-side management via distributed energy generation and storage optimization. IEEE Trans. Smart Grid 2013, 4, 866-876. [CrossRef]

58. Daryanian, B.; Bohn, R.E.; Tabors, R.D. Optimal demand-side response to electricity spot prices for storage-type customers. IEEE Trans. Power Syst. 1989, 4, 897-903. [CrossRef]

59. Huang, L.; Walrand, J.; Ramchandran, K. Optimal demand response with energy storage management. In Proceedings of the 2012 IEEE 3rd International Conference on Smart Grid Communications, Tainan, Taiwan, 5-8 November 2012.

60. Oldewurtel, F.; Ulbig, A.; Morari, M.; Andersson, G. Building control and storage management with dynamic tariffs for shaping demand response. In Proceedings of the IEEE PES International Conference and Exhibition on Innovative Smart Grid Technologies, Manchester, UK, 5-7 December 2011.

61. Wang, Z.; Gu, C.; Li, F.; Bale, P.; Sun, H. Active demand response using shared energy storage for household energy management. IEEE Trans. Smart Grid 2013, 4, 1888-1897. [CrossRef]

62. Gouveia, C.; Moreira, J.; Moreira, C.L.; Pecas Lopes, J.A. Coordinating storage and demand response for microgrid emergency operation. IEEE Trans. Smart Grid 2013, 4, 1898-1908. [CrossRef]

63. Halik, M. Optimizing Residential Battery Storage for Grid-Scale Energy Arbitrage; Heriot-Watt University: Edinburgh, UK, 2016.

64. Aghaei, J.; Alizadeh, M.I. Multi-objective self-scheduling of CHP (combined heat and power)-based microgrids considering demand response programs and ESSs (energy storage systems). Energy 2013, 55, 1044-1054. [CrossRef] 
65. Soliman, H.M.; Leon-Garcia, A. Game-theoretic demand-side management with storage devices for the future smart grid. IEEE Trans. Smart Grid 2014, 5, 1475-1485. [CrossRef]

66. Olivares, D.E.; Cañizares, C.A.; Kazerani, M. A centralized optimal energy management system for microgrids. In Proceedings of the IEEE Power and Energy Society General Meeting, San Diego, CA, USA, 24-29 July 2011.

67. Palma-Behnke, R.; Benavides, C.; Lanas, F.; Severino, B.; Reyes, L.; Llanos, J.; Saez, D. A microgrid energy management system based on the rolling horizon strategy. IEEE Trans. Smart Grid 2013, 4, 996-1006. [CrossRef]

68. Colson, C.M.; Nehrir, M.H. Comprehensive real-time microgrid power management and control with distributed agents. IEEE Trans. Smart Grid 2013, 4, 617-627. [CrossRef]

69. Kanchev, H.; Lu, D.; Colas, F.; Lazarov, V.; Francois, B. Energy management and operational planning of a microgrid with a PV-based active generator for smart grid applications. IEEE Trans. Ind. Electron. 2011, 58, 4583-4592. [CrossRef]

70. Stluka, P.; Godbole, D.; Samad, T. Energy management for buildings and microgrids. In Proceedings of the Proceedings of the IEEE Conference on Decision and Control, Orlando, FL, USA, 12-15 December 2011.

71. Jiang, Q.; Xue, M.; Geng, G. Energy management of microgrid in grid-connected and stand-alone modes. IEEE Trans. Power Syst. 2013, 28, 3380-3389. [CrossRef]

72. Chaouachi, A.; Kamel, R.M.; Andoulsi, R.; Nagasaka, K. Multiobjective intelligent energy management for a microgrid. IEEE Trans. Ind. Electron. 2013, 60, 1688-1699. [CrossRef]

73. Jin, C.; Ghosh, P.K. Coordinated usage of distributed sources for energy cost saving in micro-grid. In Proceedings of the NAPS 2011—43rd North American Power Symposium, Boston, MA, USA, 4-6 August 2011.

74. Nunna, H.K.; Doolla, S. Multiagent-based distributed-energy-resource management for intelligent microgrids. IEEE Trans. Ind. Electron. 2013, 60, 1678-1687. [CrossRef]

75. Rahbar, K.; Xu, J.; Zhang, R. An off-line optimization approach for online energy storage managementin microgrid system. In Proceedings of the 2014 IEEE International Conference on Acoustics, Speech and Signal Processing (ICASSP), Florence, Italy, 4-9 May 2014; pp. 7769-7773.

76. Zhang, Y.; Gatsis, N.; Giannakis, G.B. Robust energy management for microgrids with high-penetration renewables. IEEE Trans. Sustain. Energy 2013, 4, 944-953. [CrossRef]

77. Mateo, C.; Sánchez, Á.; Frías, P.; Rodriguez-Calvo, A.; Reneses, J. Cost-benefit analysis of battery storage in medium-voltage distribution networks. IET Gener. Transm. Distrib. 2016, 10, 815-821. [CrossRef]

78. Su, W.F.; Huang, S.J. Economic analysis for demand-side hybrid photovoltaic and battery energy storage system. IEEE Trans. Ind. Appl. 2001, 3, 2051-2057.

79. Eyer, J.; Iannucci, J.; Butler, P.C. SUR (8-2005) Estimating Electricity Storage Power Rating and Discharge Duration for Utility Transmission and Distribution Deferral. A Study for the Doe Energy Storage Program; Sandia National Laboratories: Livermore, CA, USA, 2005.

80. Salehi, J.; Safari, A.; Samadi, F. Investment Deferral of Sub-Transmission Substation Using Optimal Planning of Wind Generators and Storage Systems. J. Energy Manag. Technol. 2017, 1, 18-29.

81. Wogrin, S.; Gayme, D.F. Optimizing Storage Siting, Sizing, and Technology Portfolios in Transmission-Constrained Networks. IEEE Trans. Power Syst. 2015, 30, 3304-3313. [CrossRef]

82. Martinez, I.C.; Chen, C.-Y.; Teng, J.-H. Utilising energy storage systems to mitigate power system vulnerability. IET Gener. Transm. Distrib. 2013, 7, 790-798.

83. Stanojevic, V.; Bilton, M.; Dragovic, J.; Schofield, J.; Strbac, G. Application of demand side response and energy storage to enhance the utilization of the existing distribution network capacity. In Proceedings of the 22nd International Conference and Exhibition on Electricity Distribution (CIRED 2013), Stockholm, Sweden, 10-13 June 2013.

84. Eyer, J. Sandia Report Electric Utility Transmission and Distribution Upgrade Deferral Benefits from Modular Electricity Storage. A Study for the Doe Energy Storage Systems Program; Sandia National Laboratories: Livermore, CA, USA, 2009.

85. Thomas, A.; Saha, T.K.; Deeba, S.R.; Chakraborty, D.; Sharma, R. Evaluation of technical and financial benefits of battery-based energy storage systems in distribution networks. IET Renew. Power Gener. 2016, 10, 1149-1160.

86. Zhang, F.; Hu, Z.; Song, Y. Mixed-integer linear model for transmission expansion planning with line losses and energy storage systems. IET Gener. Transm. Distrib. 2013, 7, 919-928. [CrossRef] 
87. Nick, M.; Hohmann, M.; Cherkaoui, R.; Paolone, M. On the optimal placement of distributed storage systems for voltage control in active distribution networks. In Proceedings of the IEEE PES Innovative Smart Grid Technologies Conference Europe, Berlin, Germany, 14-17 October 2012.

88. Hill, C.A.; Such, M.C.; Chen, D.; Gonzalez, J.; Grady, W.M.K. Battery energy storage for enabling integration of distributed solar power generation. IEEE Trans. Smart Grid 2012, 3, 850-857. [CrossRef]

89. Gabash, A.; Li, P. Active-reactive optimal power flow in distribution networks with embedded generation and battery storage. IEEE Trans. Power Syst. 2012, 27, 2026-2035. [CrossRef]

90. Kabir, M.N.; Mishra, Y.; Ledwich, G.; Dong, Z.Y.; Wong, K.P. Coordinated control of grid-connected photovoltaic reactive power and battery energy storage systems to improve the voltage profile of a residential distribution feeder. IEEE Trans. Ind. Informatics 2014, 10, 967-977. [CrossRef]

91. Nick, M.; Hohmann, M.; Cherkaoui, R.; Paolone, M. Optimal location and sizing of distributed storage systems in active distribution networks. In Proceedings of the 2013 IEEE Grenoble Conference PowerTech, Grenoble, France, 16-20 June 2013.

92. Enslin, J.H.R. Dynamic reactive power and energy storage for integrating intermittent renewable energy. In Proceedings of the IEEE PES General Meeting, PES, Providence, RI, USA, 25-29 July 2010.

93. Fu, Q.; Montoya, L.F.; Solanki, A.; Nasiri, A.; Bhavaraju, V.; Abdallah, T.; Yu, D.C. Microgrid generation capacity design with renewables and energy storage addressing power quality and surety. IEEE Trans. Smart Grid 2012, 3, 2019-2027. [CrossRef]

94. Abbey, C.; Joos, G. Supercapacitor energy storage for wind energy applications. IEEE Trans. Ind. Appl. 2007, 43, 769-776. [CrossRef]

95. Hemmati, R.; Saboori, H.; Jirdehi, M.A. Stochastic planning and scheduling of energy storage systems for congestion management in electric power systems including renewable energy resources. Energy 2017, 133, 380-387. [CrossRef]

96. Oh, H. Optimal planning to include storage devices in power systems. IEEE Trans. Power Syst. 2011, 26, 1118-1128. [CrossRef]

97. Nick, M.; Cherkaoui, R.; Paolone, M. Optimal siting and sizing of distributed energy storage systems via alternating direction method of multipliers. Int. J. Electr. Power Energy Syst. 2015, 72, 33-39. [CrossRef]

98. Alnaser, S.W.; Ochoa, L.F. Optimal Sizing and Control of Energy Storage in Wind Power-Rich Distribution Networks. IEEE Trans. Power Syst. 2016, 31, 2004-2013. [CrossRef]

99. Lim, M. Optimization of Sizing and Placement of Energy Storage Systems on an Islanded Grid with High Penetration of Renewables; University of Colorado, Boulder: Boulder, CO, USA, 2014.

100. Khani, H.; Zadeh, M.R.D.; Hajimiragha, A.H. Transmission Congestion Relief Using Privately Owned Large-Scale Energy Storage Systems in a Competitive Electricity Market. IEEE Trans. Power Syst. 2016, 31, 1449-1458. [CrossRef]

101. Del Rosso, A.D.; Eckroad, S.W. Energy storage for relief of transmission congestion. IEEE Trans. Smart Grid 2014, 5, 1138-1146. [CrossRef]

102. Vargas, L.S.; Bustos-Turu, G.; Larrain, F. Wind Power Curtailment and Energy Storage in Transmission Congestion Management Considering Power Plants Ramp Rates. IEEE Trans. Power Syst. 2015, 30, 2498-2506. [CrossRef]

103. Aghamohammadi, M.R.; Abdolahinia, H. A new approach for optimal sizing of battery energy storage system for primary frequency control of islanded Microgrid. Int. J. Electr. Power Energy Syst. 2014, 54, 325-333. [CrossRef]

104. Oudalov, A.; Chartouni, D.; Ohler, C. Optimizing a battery energy storage system for primary frequency control. IEEE Trans. Power Syst. 2007, 22, 1259-1266. [CrossRef]

105. Mercier, P.; Cherkaoui, R.; Oudalov, A. Optimizing a battery energy storage system for frequency control application in an isolated power system. IEEE Trans. Power Syst. 2009, 24, 1469-1477. [CrossRef]

106. Bhargava, B. Application of an energy source power system stabilizer on thé $10 \mathrm{mw}$ battery energy storage system at chino substation. IEEE Trans. Power Syst. 1998, 13, 145-151. [CrossRef]

107. Aditya, S.K.; Das, D. Battery energy storage for load frequency control of an interconnected power system. Electr. Power Syst. Res. 2001, 58, 179-185. [CrossRef]

108. Delille, G.; François, B.; Malarange, G. Dynamic frequency control support by energy storage to reduce the impact of wind and solar generation on isolated power system's inertia. IEEE Trans. Sustain. Energy 2012, 3, 931-939. [CrossRef] 
109. Lu, C.F.; Liu, C.C.; Wu, C.J. Effect of battery energy storage system on load frequency control considering governor deadband and generation rate constraint. IEEE Trans. Energy Convers. 1995, 10, 555-561.

110. Choi, J.H.; Kim, J.C. Advanced voltage regulation method of power distribution systems interconnected with dispersed storage and generation systems (revised). IEEE Trans. Power Deliv. 2001, 16, 329-334. [CrossRef]

111. Daeseok, R.; Kita, H.; Hasegawa, J.; Nishiya, K. A study on the optimal voltage regulation methods in power distribution systems interconnected with dispersed energy storage and generation systems. In Proceedings of the 1995 International Conference on Energy Management and Power Delivery (EMPD '95), Singapore, 21-23 November 1995; Volume 2, pp. 702-707.

112. Li, B.; Chen, M.; Cheng, T.; Li, Y.; Arshad Shehzad Hassan, M.; Xu, R.; Chen, T. Distributed Control of Energy-Storage Systems for Voltage Regulation in Distribution Network with High PV Penetration. In Proceedings of the 2018 UKACC 12th International Conference on Control, Sheffield, UK, 5-7 September 2018.

113. Khadkikar, V.; Varma, R.K.; Seethapathy, R. Grid voltage regulation utilizing storage batteries in PV solar-Wind plant based distributed generation system. In Proceedings of the 2009 IEEE Electrical Power and Energy Conference (EPEC), Montreal, QC, Canada, 22-23 October 2009.

114. Wang, Y.; Tan, K.T.; Peng, X.Y.; So, P.L. Coordinated Control of Distributed Energy-Storage Systems for Voltage Regulation in Distribution Networks. IEEE Trans. Power Deliv. 2016, 31, 1132-1141. [CrossRef]

115. Nazaripouya, H.; Wang, Y.; Chu, P.; Pota, H.R.; Gadh, R. Optimal sizing and placement of battery energy storage in distribution system based on solar size for voltage regulation. In Proceedings of the IEEE Power and Energy Society General Meeting, Denver, CO, USA, 26-30 July 2015.

116. Venu, C.; Riffonneau, Y.; Bacha, S.; Baghzouz, Y. Battery storage system sizing in distribution feeders with distributed photovoltaic systems. In Proceedings of the 2009 IEEE Bucharest PowerTech: Innovative Ideas Toward the Electrical Grid of the Future, Bucharest, Romania, 28 June-2 July 2009.

117. Yang, Y.; Li, H.; Aichhorn, A.; Zheng, J.; Greenleaf, M. Sizing strategy of distributed battery storage system with high penetration of photovoltaic for voltage regulation and peak load shaving. IEEE Trans. Smart Grid 2014, 5, 982-991. [CrossRef]

118. Zillmann, M.; Yan, R.; Saha, T.K. Regulation of distribution network voltage using dispersed battery storage systems: A case study of a rural network. In Proceedings of the IEEE Power and Energy Society General Meeting, San Diego, CA, USA, 24-29 July 2011.

119. Dusonchet, L.; Ippolito, M.G.; Telaretti, E.; Zizzo, G.; Graditi, G. An optimal operating strategy for combined RES-based generators and electric storage systems for load shifting applications. In Proceedings of the International Conference on Power Engineering, Energy and Electrical Drives, Istanbul, Turkey, 13-17 May 2013.

120. Lu, C.; Xu, H.; Pan, X.; Song, J. Optimal sizing and control of battery energy storage system for peak load shaving. Energies 2014, 7, 8396-8410. [CrossRef]

121. Fathima, H.; Palanisamy, K. Optimized Sizing, Selection, and Economic Analysis of Battery Energy Storage for Grid-Connected Wind-PV Hybrid System. Model. Simul. Eng. 2015, 2015, 16. [CrossRef]

122. Di Giorgio, A.; Pimpinella, L.; Liberati, F. A model predictive control approach to the load shifting problem in a household equipped with an energy storage unit. In Proceedings of the 2012 20th Mediterranean Conference on Control and Automation (MED), Barcelona, Spain, 3-6 July 2012.

123. Oudalov, A.; Cherkaoui, R.; Beguin, A. Sizing and optimal operation of battery energy storage system for peak shaving application. In Proceedings of the 2007 IEEE Lausanne Power Tech, Lausanne, Switzerland, 1-5 July 2007.

124. Brivio, C.; Mandelli, S.; Merlo, M. Battery energy storage system for primary control reserve and energy arbitrage. Sustain. Energy Grids Netw. 2016, 6, 152-165. [CrossRef]

125. Fares, R.L.; Webber, M.E. A flexible model for economic operational management of grid battery energy storage. Energy 2014, 78, 768-776. [CrossRef]

126. Tan, X.; Wu, Y.; Tsang, D.H.K. Pareto Optimal Operation of Distributed Battery Energy Storage Systems for Energy Arbitrage under Dynamic Pricing. IEEE Trans. Parallel Distrib. Syst. 2016, 27, 2103-2115. [CrossRef]

127. Xi, X.; Sioshansi, R.; Marano, V. A stochastic dynamic programming model for co-optimization of distributed energy storage. Energy Syst. 2014, 5, 475-505. [CrossRef]

128. Nottrott, A.; Kleissl, J.; Washom, B. Energy dispatch schedule optimization and cost benefit analysis for grid-connected, photovoltaic-battery storage systems. Renew. Energy 2013, 55, 230-240. [CrossRef] 
129. Bradbury, K.; Pratson, L.; Patiño-Echeverri, D. Economic viability of energy storage systems based on price arbitrage potential in real-time U.S. electricity markets. Appl. Energy 2014, 114, 512-519. [CrossRef]

130. Grillo, S.; Marinelli, M.; Massucco, S.; Silvestro, F. Optimal Management Strategy of a Battery-Based Storage System to Improve Renewable Energy Integration in Distribution Networks. IEEE Trans. Smart Grid 2012, 3, 950-958. [CrossRef]

131. Wankmüller, F.; Thimmapuram, P.R.; Gallagher, K.G.; Botterud, A. Impact of battery degradation on energy arbitrage revenue of grid-level energy storage. J. Energy Storage 2017, 10, 56-66. [CrossRef]

132. Cheng, B.; Powell, W. Co-optimizing Battery Storage for the Frequency Regulation and Energy Arbitrage Using Multi-Scale Dynamic Programming. IEEE Trans. Smart Grid 2016, 9, 1997-2005. [CrossRef]

133. Kunisch, H.-J.; Kramer, K.G.; Dominik, H. Battery Energy Storage Another Option for Load-Frequency-Control and Instantaneous Reserve. IEEE Trans. Energy Convers. 2009, EC-1, 41-46. [CrossRef]

134. Sossan, F.; Paolone, M. Integration and Operation of Utility-Scale Battery Energy Storage Systems: The EPFL's Experience. IFAC PapersOnLine 2016, 49, 433-438. [CrossRef]

135. Khalid, M.; Savkin, A.V. Model predictive control based efficient operation of battery energy storage system for primary frequency control. In Proceedings of the 11th International Conference on Control, Automation, Robotics and Vision (ICARCV), Singapore, 7-10 December 2010.

136. Chang, B.; Kim, C.; Kim, T.; Jeon, W.; Shin, S.; Han, H. Demonstration Study on the Large-Scale Battery Energy Storage for Renewables Integration. Energy Environ. 2015, 26, 183-194. [CrossRef]

137. Sigrist, L.; Lobato, E.; Rouco, L. Energy storage systems providing primary reserve and peak shaving in small isolated power systems: An economic assessment. Int. J. Electr. Power Energy Syst. 2013, 53, 675-683. [CrossRef]

138. Faunce, T.A.; Prest, J.; Su, D.; Hearne, S.J.; Iacopi, F. On-grid batteries for large-scale energy storage: Challenges and opportunities for policy and technology. MRS Energy Sustain. 2018, 5, E11. [CrossRef]

139. European Commission. The Future Role and Challenges of Energy Storage; European Commission: Luxembourg City, Luxembourg, 2012.

140. Teleke, S. Energy Storage Overview: Applications, Technologies and Economical Evaluation; Quanta Technology: Raleigh, NC, USA, 2011.

141. Rastler, D. Electricity Energy Storage Technology Options; EPRI: Palo Alto, CA, USA, 2010.

142. Vazquez, S.; Lukic, S.M.; Galvan, E.; Franquelo, L.G.; Carrasco, J.M. Energy storage systems for transport and grid applications. IEEE Trans. Ind. Electron. 2010, 57, 3881-3895. [CrossRef]

143. Quanta Technology. Electric Energy Storage Systems; Quanta Technology: Raleigh, NC, USA, 2013.

144. Schimpe, M.; Becker, N.; Lahlou, T.; Hesse, H.C.; Herzog, H.-G.; Jossen, A. Energy efficiency evaluation of grid connection scenarios for stationary battery energy storage systems. Energy Procedia 2018, 155, 77-101. [CrossRef]

145. Hesse, H.C.; Schimpe, M.; Kucevic, D.; Jossen, A. Lithium-ion battery storage for the grid-A review of stationary battery storage system design tailored for applications in modern power grids. Energies 2017, 10, 2107. [CrossRef]

146. Lawder, M.T.; Suthar, B.; Northrop, P.W.C.; De, S.; Hoff, C.M.; Leitermann, O.; Crow, M.L.; Santhanagopalan, S.; Subramanian, V.R. Battery energy storage system (BESS) and battery management system (BMS) for grid-scale applications. Proc. IEEE 2014, 102, 1014-1030. [CrossRef]

147. Liserre, M.; Sauter, T.; Hung, J. Future Energy Systems: Integrating Renewable Energy Sources into the Smart Power Grid Through Industrial Electronics. IEEE Ind. Electron. Mag. 2010, 4, 18-37. [CrossRef]

148. Dubal, D.P.; Ayyad, O.; Ruiz, V.; Gómez-Romero, P. Hybrid energy storage: The merging of battery and supercapacitor chemistries. Chem. Soc. Rev. 2015, 44, 1777-1790. [CrossRef] [PubMed]

149. Denholm, P.; Ela, E.; Kirby, B.; Milligan, M. The Role of Energy Storage with Renewable Electricity Generation; NREL: Golden, CO, USA, 2010.

150. Bose, B.K. Global energy scenario and impact of power electronics in 21st century. IEEE Trans. Ind. Electron. 2013, 60, 2638-2651. [CrossRef]

151. Li, P. Energy storage is the core of renewable technologies. IEEE Nanotechnol. Mag. 2008, 2, 13-18. [CrossRef]

152. Acha, S. Modelling Distributed Energy Resources in Energy Service Networks; Institution of Engineering and Technology: London, UK, 2013; ISBN 9781849195591.

153. Akinyele, D.O.; Rayudu, R.K. Review of energy storage technologies for sustainable power networks. Sustain. Energy Technol. Assess. 2014, 8, 74-91. [CrossRef] 
154. South Australia's Tesla Battery on Track to Make Back a Third of Cost in a Year | Technology | The Guardian. Available online: https://www.theguardian.com/technology/2018/sep/27/south-australias-tesla-battery-ontrack-to-make-back-a-third-of-cost-in-a-year (accessed on 26 June 2019).

155. Elon Musk's Giant Battery Is Now Delivering Power to South Australia-The Verge. Available online: https://www.theverge.com/2017/12/1/16723186/elon-musk-battery-launched-south-australia (accessed on 25 June 2019).

156. Uddin, K.; Gough, R.; Radcliffe, J.; Marco, J.; Jennings, P. Techno-economic analysis of the viability of residential photovoltaic systems using lithium-ion batteries for energy storage in the United Kingdom. Appl. Energy 2017, 206, 12-21. [CrossRef]

157. MIT News. Battery Challenges: Cost and Performance. Available online: http://news.mit.edu/2016/batterychallenges-cost-and-performance-1102 (accessed on 10 April 2019).

158. Solar-Estimate. How Long do Lithium Ion Batteries Last? Available online: https://www.solar-estimate.org/ news/2018-04-11-how-long-do-lithium-ion-batteries-last (accessed on 10 April 2019).

159. California ISO. Advancing and Maximizing the Value of Energy Storage Technology: A California Roadmap; California ISO: Folsom, CA, USA, 2014.

160. USA Congress. STORAGE 2011 Act; USA Congress: Washington, DC, USA, 2011.

161. RES LEGAL Europe. Feed In Tariff: Legal Sources on Renewable Energy. Available online: http://www.res-legal.eu/search-by-country/germany/single/s/res-e/t/promotion/aid/feed-in-tariffeeg-feed-in-tariff/lastp/135/ (accessed on 10 April 2019).

162. Whittingham, M.S. History, evolution, and future status of energy storage. Proc. IEEE 2012, 100, 1518-1534. [CrossRef]

163. Chakrabarti, B.B.; Rayudu, R.K. Balancing wind intermittency using hydro reserves and demand response. In Proceedings of the 2012 IEEE International Conference on Power System Technology (POWERCON), Auckland, New Zealand, 30 October-2 November 2012.

164. Dunn, B.; Kamath, H.; Tarascon, J.-M. Electrical Energy Storage for the Grid: A Battery of Choices. Science 2011, 334, 928-935. [CrossRef] [PubMed] 